\title{
ESSAY
}

\section{FREEDOM OF SPEECH, PERMISSIBLE TAILORING AND TRANSCENDING STRICT SCRUTINY}

\author{
EUGENE VOLOKH $†$
}

\section{INTRODUCTION}

The Supreme Court has often held that content-based restrictions on fully protected speech are valid if they are "narrowly tailored to serve a compelling state interest." I believe this is wrong.

It is wrong descriptively: There are restrictions the Court would strike down-of which I'll give examples-even though they are narrowly tailored to serve a compelling state interest. It is wrong normatively: In striking these restrictions down, the Court would, in my view, be correct. And the official test is not just wrong but pernicious. It risks leading courts and legislators to the wrong conclusions, it causes courts to apply the test disingenuously, and it distracts us from looking for a better approach. ${ }^{2}$

$\dagger$ Acting Professor, UCLA Law School (volokh@law.ucla.edu). Many thanks to Daniel Bussel, Evan Caminker, David Cruz, Michael Kent Curtis, Julian Eule, Robert Goldstein, Tom Grey, Jerry Kang, Kenneth Karst, Doug Laycock, Sanford Levinson, Daniel Lowenstein, Sidney Rosenzweig, Gary Schwartz, David Sklansky, David Sobelsohn, Jonathan Varat, James Weinstein, Stephen Yeazell and the members of the UCLA American Politics Discussion Group for their advice.

1 See, e.g., Austin v. Michigan Chamber of Commerce, 494 U.S. 652, 655 (1990); Boos v. Barry, 485 U.S. 312, 334 (1988) (plurality); see also Burson v. Freeman, 504 U.S. 191, 198 (1992) (plurality); Board of Airport Comm'rs v. Jews for Jesus, Inc., 482 U.S. 569, 573 (1987); Cornelius v. NAACP Legal Defense and Educ. Fund, Inc., 473 U.S. 788, 800 (1985); United States v. Grace, 461 U.S. 171, 177 (1983); Perry Educ. Ass'n v. Perry Local Educators' Ass'n, 460 U.S. 37, 45 (1983).

Strict scrutiny is the rule, of course, only if the restrictions are imposed by the government acting as sovereign, and not as, for instance, employer, landlord, or primary or secondary school educator, where it has more discretion. Even when the government is acting as sovereign, it may have more latitude in particular areas such as broadcasting regulations, copyright law and the right of publicity. But strict scrutiny is still the general rule, and is the highwater mark of speech protection-in all the non-strict-scrutiny contexts the rule is more tolerant of speech restrictions than is strict scrutiny.

${ }^{2}$ My criticism here is not that the strict scrutiny test can't produce predictable results, though there's a good deal of merit to this point. See, e.g., Eu v. San Francisco County Democratic Cent. Comm., 489 U.S. 214, 234 (1989) (Stevens, J., concurring); 
After briefly restating strict scrutiny doctrine (Part I), I'll give three examples of speech restrictions that in my view would pass muster if the strict scrutiny framework were taken seriously, but that nonetheless would and should be struck down (Part II). I'll then point to some of the costs of the Court's reliance on an unsound doctrinal structure (Part III), and finally (Parts IV and V) suggest the rough foundations-and, I concede, only the rough foundations-of two alternative approaches.

The first alternative is for the Court to acknowledge that there is a third prong to strict scrutiny, which I call "permissible tailoring." Rather than just asking about the strength of the government's interest, or about whether the means are narrowly drawn to accomplish the interest, it asks whether the means are nonetheless impermissible: Whether, no matter how narrow they are, and no matter how compelling an interest they serve, the means are still contrary to some basic prohibitions that the Free Speech Clause imposes. This, I'll argue, is an inquiry quite distinct from what the Court requires under the "narrow tailoring" prong.

The second alternative, which I prefer, is for the Court to shift away from means-ends scrutiny, and toward an approach that operates through categorical rules-such as a per se ban on contentbased speech restrictions imposed by the government as sovereign-coupled with categorical exceptions, such as the exceptions for fighting words, obscenity and copyright. I think this framework would better direct the Court's analysis, and would avoid the erroneous results that strict scrutiny seems to command.

\section{A BRIEF RESTATEMENT OF STRICT SCRUTINY DOCTRINE}

Content-based speech restrictions, the Court says, are constitutional if they are "narrowly tailored to serve a compelling state interest"; 3 many have aptly called this an "ends and means" inquiry. ${ }^{4}$ The Court makes a normative judgment about the ends: Is the interest important enough to justify a speech restriction? ${ }^{5}$ And the

Illinois Bd. of Elections v. Socialist Workers Party, 440 U.S. 173, 188 (1979) (Blackmun, J., concurring). Rather, it is that the strict scrutiny test can in many cases produce the wrong results.

${ }^{3}$ See supra note 1.

${ }^{4}$ See, e.g., Sable Communications v. FCC, 492 U.S. 115, 126 (1989); Lillian BeVier, Campaign Finance Reform: Special Arguments, Intractable Dilemmas, 94 COLUM. L. REV. 1258, 1278 (1994); see also Adarand Contructors v. Pena, 115 S. Ct. 2097, 2117 (1995) (race classification context); Randall Kennedy, The State, Criminal Law, and Racial Discrimination: A Comment, 107 HARV. L. REV. 1255, 1265 n.45 (1994) (same).

${ }^{5}$ Some have suggested that "public purpose" is a better term than "government 
Court makes a primarily empirical judgment about the means: If the means do not actually further the interest, are too broad, are too narrow, or are unnecessarily burdensome, then the government can and should serve the end through a better-drafted law. ${ }^{6}$

The Court has set forth four general principles related to compelling interests:

1. The government can have no compelling interest in privileging particular subclasses of core protected speech-discussion about economic, social and political matters-over other subclasses. All such core protected speech "rest[s] on the highest rung of the hierarchy of First Amendment values."7 The mere interest in furthering a subset of this speech (for instance, labor picketing) "without more, cannot justify [a content-based] exemption" for such speech. ${ }^{8}$

2. Avoidance of offense and restriction of bad ideas are not compelling interests by themselves: "[T] prohibit the expression of an idea simply because society finds the idea itself offensive or disagreeable." 9 Note though that the word "simply" here, like the phrase "without more" in the quote at the end of the last paragraph, leaves a good deal uncertain. What if society finds an idea offensive and the resulting offense leads to a particular bad result, such as employees of a particular religion, race or sex becoming so offended by workplace speech that they reasonably conclude that their workplaces have become hostile environments? ${ }^{10}$

interest," see Stephen E. Gottlieb, Compelling Governmental Interests and Constitutional Discourse, 55 ALB. L. REV. 549, 552 (1992), and much can be said for this view. But "government interest" is so firmly a part of the strict scrutiny test that I prefer to stick with it in this context.

${ }^{6}$ I say "primarily empirical" because there are some subsidiary normative judgments involved in deciding, for instance, how much over-or underinclusiveness is too much, or whether a particular alternative is less burdensome. Cf. Sable Communications, 492 U.S. at 131-32 (Scalia, J., concurring).

${ }^{7}$ Carey v. Brown, 447 U.S. 455, 467 (1980); see also Consolidated Edison Co. v. Public Serv. Comm'n, 447 U.S. 530, 537-38 (1980).

${ }^{8}$ Carey, 447 U.S. at 467.

${ }^{9}$ Simon \& Schuster, Inc. v. Members of the N.Y. State Crime Victims Bd., 502 U.S. 105, 118 (1991) (quoting Texas v. Johnson, 491 U.S. 397, 414 (1989)).

${ }^{10}$ Compare Suzanne Sangree, Title VII Prohibitions Against Hostile Environment Sexual Harassment and the First Amendment: No Collision in Sight, 47 RUTGERS L. REV. 461 (1995) (arguing that speech restrictions would be constitutional in such a case) with Kingsley R. Browne, Title VII as Censorship: Hostile-Environment Harassment and the First Amendment, 52 OHIO ST. L.J. 481 (1991) (arguing that such speech restrictions would be unconstitutional) and Eugene Volokh, Comment, Freedom of Speech and Workplace Harassment, 39 UCLA L. REV. 1791 (1992) (taking a middle course); see also Kingsley R. Browne, Workplace Censorship: A Response to Professor Sangree, 47 RUTGERS L. REV. 579 
What if society wants to prevent disclosure of embarrassing facts about people, because people might find it "offensive or disagreeable" for their neighbors to know these facts about them?"11 The answers to both these questions, and to others like them, are far from settled.

3. A law's underinclusiveness-its failure to reach all speech that implicates the interest-may be evidence that an interest is not compelling, because it suggests that the government itself doesn't see the interest as compelling enough to justify a broader statute. ${ }^{12}$

4. An interest might itself be impermissibly underinclusive, even if the law is quite narrowly fitted to the interest: The government (at least under some circumstances) may not assert a compelling interest in fighting one particular ill, and then refuse to deal with other ills that seem almost indistinguishable. There's only one case that squarely raises this point, so the boundaries of this principle are still quite vague. ${ }^{13}$

Outside these general areas, the Court has recognized a number of specific interests as compelling: "maintaining a stable political system"; 14 ensuring that "criminals do not profit from their crimes" and that crime victims are compensated by the criminals; ${ }^{15}$ protecting the right of "members of groups that have historically been subjected to discrimination . . . to live in peace where they wish"; ${ }^{16}$ protecting voters from confusion, undue influence and intimidation; ${ }^{17}$ preventing vote-buying; ${ }^{18}$ "eliminating from the political

(1995); Eugene Volokh, How Harassment Law Restricts Free Speech, 47 RuTGERS L. REV. 563 (1995); Suzanne Sangree, A Reply to Professors Volokh and Browne, 47 RUTGERS L. REV. 595 (1995).

"See Florida Star v. B.J.F., 491 U.S. 524, 541 (1989) (declining to decide whether the "disclosure of private facts" tort is constitutional).

12 See id. at 542 (Scalia, J., concurring in part and in the judgment); Carey, 447 U.S. at 465 .

${ }^{13}$ The case is Simon \& Schuster, Inc. v. Members of the N.Y. State Crime Victims Bd., 502 U.S. 105 (1991). The government argued that it had an interest in "ensuring that criminals do not profit from storytelling about their crimes before their victims have a meaningful opportunity to be compensated for their injuries." Id. at 119. The Court agreed that the government had a compelling interest in "ensuring that criminals do not profit from their crimes" generally. Nonetheless, the Court rejected the government's proffered interest-even though it was a subset of the interest the Court concluded was compelling-because the government's interest swept too narrowly: The government could offer no "justification for a distinction" between profiting from speech about one's crime and profiting from the crime in other ways. Id. at 119-20.

${ }_{14}$ Eu v. San Francisco County Democratic Cent. Comm., 489 U.S. 214, 226 (1989).

${ }^{15}$ Simon ED Schuster, 502 U.S. at 118-19.

${ }^{16}$ R.A.V. v. City of St. Paul, 505 U.S. 377, 395 (1992).

17 See Burson v. Freeman, 504 U.S. 191, 199 (1992) (plurality). 
process the corrosive effect of political 'war chests' amassed with the aid of the legal advantages given to corporations"; ${ }^{19}$ and protecting "the unique role [of] the press," which may justify otherwise impermissible speaker discrimination. ${ }^{20}$ In the associational rights and religious freedom contexts, the Court has held that preventing race and sex discrimination, ${ }^{21}$ preserving the integrity of the tax system, ${ }^{22}$ and "procuring the manpower necessary for military purposes"23 are also compelling. Query whether these interests apply equally in the free speech context.

On the other hand, the Court has held that the interests in "equalizing the relative ability of individuals and groups to influence the outcome of elections," 24 in "reducing the allegedly skyrocketing costs of political campaigns," ${ }^{25}$ in "preserving party unity during a primary," 26 and in protecting speakers who "are incapable of deciding for themselves the most effective way to exercise their First Amendment rights" ${ }^{27}$ are not compelling. If the substantive due process and equal protection cases are any guide, neither is the interest in administrative efficiency. ${ }^{28}$

Most cases striking down speech restrictions, however, rely primarily on the narrow tailoring prong, which, according to the Court, contains four components: ${ }^{29}$

${ }^{18}$ See Buckley v. Valeo, 424 U.S. 1, 27 (1976).

${ }^{19}$ Austin v. Michigan Chamber of Commerce, 494 U.S. 652, 666 (1990).

${ }^{20} \mathrm{Id}$. at 667.

2I See Roberts v. United States Jaycees, 468 U.S. 609, 623 (1984) (sex discrimination); Bob Jones Univ. v. United States, 461 U.S. 574, 604 (1983) (race discrimination).

${ }^{22}$ See United States v. Lee, 455 U.S. 252, 258-59 (1982).

${ }^{29}$ Gillette v. United States, 401 U.S. 437,462 (1971).

${ }^{24}$ Buckley v. Valeo, 424 U.S. 1, 48-49 (1976).

${ }^{25} \mathrm{Id}$. at 57.

${ }^{26}$ Eu v. San Francisco County Democratic Cent. Comm., 489 U.S. 214, 228 (1989).

${ }^{27}$ Riley v. National Fed'n for the Blind, 487 U.S. 781, 790 (1988).

${ }^{28}$ See Gity of Richmond v. J.A. Croson Co., 488 U.S. 469, 508 (1989) (race classification context); Carey v. Population Servs. Int'l, 431 U.S. 678, 691 (1977) (contraceptive rights context); Police Dep't of Chicago v. Mosley, 408 U.S. 92, 102 n.9 (1972) (holding that, in free speech cases, "small administrative convenience" is not a compelling interest).

${ }^{29}$ I speak here of narrow tailoring in the context of content-based restrictions. Content-neutral restrictions are also supposed to be "narrowly tailored" to significant government interests, but narrow tailoring there is quite different than where contentbased restrictions are involved. See Ward v. Rock Against Racism, 491 U.S. 781, 799 n.6 (1989). Content-neutral restrictions need not, for instance, be the least restrictive alternatives, and it seems they might be valid even if they are underinclusive. See id. (as to least restrictive alternative); Members of the City Council v. Taxpayers for Vincent, 466 U.S. 789, 810-11 \& n.28 (1984) (as to underinclusiveness). 
1. Advancement of the Interest. For a law to be narrowly tailored, the government must prove to the Court's satisfaction that the law actually advances the interest. ${ }^{30}$ The government need not, however, prove this scientifically; a sufficiently persuasive common-sense foundation is enough. ${ }^{31}$

2. No Overinclusiveness. A law is not narrowly tailored if it restricts a significant amount of speech that doesn't implicate the government interest. ${ }^{32}$ The theory here is that if the government can serve the interest while burdening less speech, it should.

3. Least Restrictive Alternative. A law is not narrowly tailored if there are less speech-restrictive means available that would serve the interest essentially as well as would the speech restriction. ${ }^{33}$ The justification for this requirement is similar to that for the overinclusiveness inquiry, though one can imagine a law that isn't overinclusive-that restricts only the speech that implicates the interest-but is still not the least restrictive alternative. This might happen when the interest can be served equally well with a restriction on unprotected conduct rather than on speech, ${ }^{34}$ or with a restriction that merely limits the speech in some ways rather than barring it altogether. ${ }^{35}$ The government need not, however, choose an alternative that "fall[s] short of serving [the] compelling interests." 36

${ }^{30}$ See, e.g., Eu, 489 U.S. at 226, 228-29 (1989); Meyer v. Grant, 486 U.S. 414, 426 (1988); FEC v. Massachusetts Citizens for Life, Inc., 479 U.S. 238, 262 (1986); Globe Newspaper Co. v. Superior Court, 457 U.S. 596, 609-10 (1982); First Nat'l Bank v. Bellotti, 435 U.S. 765, 789-90 (1978); Buckley v. Valeo, 424 U.S. 1, 45-47, 53 (1976).

${ }^{31}$ See, e.g., Burson v. Freeman, 504 U.S. 191, 211 (1992) (plurality) (pointing to a "long history, a substantial consensus, and simple common sense" as support for a finding of narrow tailoring); Austin v. Michigan Chamber of Commerce, 494 U.S. 652, 660 (1990); Buckley, 424 U.S. at 26-27 (looking to longstanding political practice).

32 See, e.g., Simon \& Schuster, Inc. v. Members of the N.Y. State Crime Victims Bd., 502 U.S. 105, 120-21 (1991); FEC v. National Conservative Political Action Comm., 470 U.S. 480, 500-01 (1985); First Nat'l Bank, 435 U.S. at 794.

${ }^{3 s}$ See, e.g., Rutan v. Republican Party, 497 U.S. 62, 74 (1990); Sable Communications v. FCG, 492 U.S. 115, 126 (1989); Florida Star v. B.J.F., 491 U.S. 524, 538 (1989); Boos v. Barry, 485 U.S. 312, 329 (1988); Minneapolis Star \& Tribune Co. v. Minnesota Comm'r of Revenue, 460 U.S. 575, 586 (1983).

${ }^{34}$ See, e.g., Meyer v. Grant, 486 U.S. 414, 425-28 (1988); Boos, 485 U.S. at 326-29.

${ }^{35}$ See, e.g., Sable Communications, 492 U.S. at 129-30.

${ }^{36}$ Burson v. Freeman, 504 U.S. 191, 206 (1992) (plurality); see also Buckley v. Valeo, 424 U.S. 1, 28 (1976).

Justice Thomas's partial dissent in Colorado Republican Fed. Campaign Comm. v. FEC, 116 S. Ct. 2309 (1996), takes a different approach, arguing that the fact that the alternatives "are not completely effective in [serving the interest] is no justification for the conclusion that prophylactic controls on funding activity are narrowly tailored." Id. at 2329. In Justice Thomas's view, a law may be invalid even if it's the 
These three components are closely related, and all of them could be subsumed within the "least restrictive alternative" inquiry. If the law doesn't actually advance the interest, then not having the law at all would be a less restrictive but equally effective alternative. Likewise, if the law is overinclusive, then a narrower law that exempted speech which doesn't implicate the interest would be less restrictive and equally effective. When the Court says, as it sometimes does, that a law must be "'necessary to serve a compelling state interest, " 37 it seems to be referring to these three components. ${ }^{38}$

4. No Underinclusiveness. Finally, a law is not narrowly tailored if it fails to restrict a significant amount of speech that harms the government interest to about the same degree as does the restricted speech. ${ }^{39}$ Underinclusiveness might suggest, as mentioned above, that the interest isn't very important, or that the government's real interest wasn't the stated one but was rather just a desire to favor one form of speech over another, or to suppress offensive or otherwise disfavored speech. ${ }^{40}$ Underinclusiveness may also show the presence of content discrimination beyond that justified by the compelling interest. Because content discrimination is disfavored, and allowed only when justified by a compelling interest, the presence of this extra, unjustified distinction makes the law unconstitutional. ${ }^{41}$

only really effective way to serve the interest-the First Amendment simply "constrains Congress' ability to accomplish certain goals." Id. But while there's much to recommend this approach, Justice Thomas was writing only for himself, and he made quite clear that his approach was premised on a rejection of the Court's contrary conclusion in Buckley.

Note that Justice Thomas doesn't seem to be focusing on the "completely" in "completely effective": He isn't just saying that the other alternatives are almost as effective-in fact, they don't seem to be-but rather that the speech restriction may be unconstitutional even if the alternatives are considerably less effective.

${ }^{37}$ Burson, 504 U.S. at 198 (quoting Perry Educ. Ass'n v. Perry Local Educators' Ass'n, 460 U.S. 37, 45 (1983)); Simon \& Schuster, Inc. v. Members of the N.Y. State Crime Victims Bd., 502 U.S. 105, 117 (1992).

${ }^{38}$ See, e.g., Simon $\mathcal{E}^{\circ}$ Schuster, 502 U.S. at 120-21.

${ }^{39}$ See, e.g., Florida Star v. B.J.F., 491 U.S. 524, 540 (1989); Carey v. Brown, 447 U.S. 455, 465 (1980); First Nat'l Bank v. Bellotti, 435 U.S. 765, 793 (1978); Erznoznik v. City of Jacksonville, 422 U.S. 205, 213-14 (1975) (not specifically mentioning strict scrutiny, but discussing over- and underinclusiveness).

${ }^{40}$ See, e.g., City of Richmond v. J.A. Croson Co., 488 U.S. 469, 493 (1989) (race classification context); Arkansas Writers' Project, Inc. v. Ragland, 481 U.S. 221, 232 (1987); First Nat'l Bank, 435 U.S. at 793; cf. City of Cleburne v. Cleburne Living Ctr., 473 U.S. 432, 450 (1985) (inferring from a law's dramatic underinclusiveness relative to its stated purpose that the true purpose was something else).

41 See Erznoznik, 422 U.S. at 215; cf. R.A.V. v. City of St. Paul, 505 U.S. 377, 386 (1992). In R.A.V., the Court asserted that "the First Amendment imposes not an 
Some cases have condemned content distinctions because speech on both sides of the line implicated the interest equally. For instance, the Court has held that a bar on nonlabor residential picketing was not narrowly tailored to the interest in preserving residential privacy because labor picketing and nonlabor picketing were equally intrusive. ${ }^{42}$ Such cases turn on underinclusiveness principles-they strike down laws for being strikingly underinclusive with respect to the interest they purport to serve.

On their faces, all four of these prohibitions call for primarily empirical judgments-judgments about the closeness of the fit between the law and the interest-rather than normative ones. Once the Court concludes that the interest is compelling, the strict scrutiny framework requires that the free speech interest yield to a narrowly drawn law. The narrow-tailoring prong, then, involves essentially factual questions about whether the law is indeed narrowly drawn: Does the law further the interest; is the law limited to speech that implicates the interest; does the law cover all such speech; are there less restrictive alternatives that will serve the interest equally well?

'underinclusiveness' limitation but a 'content discrimination' limitation upon a State's prohibition of proscribable speech," but in context this seems to mean only that underinclusiveness is not an issue in the absence of content discrimination. See id. at 387 (giving as the only example a ban on obscenity in some media and not other media, and concluding that such a ban wouldn't be subject to underinclusiveness analysis because "it would not discriminate on the basis of content").

$R . A . V$. certainly did not purport to overrule the cases cited in the last several footnotes which have held that an underinclusiveness inquiry is an inherent part of determining whether a content discrimination is permissible. See, e.g., Florida Star, 491 U.S, at 540; id. at 541-42 (Scalia, J., concurring in part and in the judgment) (specifically concluding that the challenged content discrimination must be set aside solely on the grounds that it is underinclusive; Justice Scalia was also the author of the R.A.V. opinion). And, of course, even on its own terms the Court's language is limited to selective prohibitions of proscribable speech, such as fighting words, rather than fully protected speech.

42 See Carey, 447 U.S. at 467-69 ; see also Simon \& Schuster, Inc. v. Members of the N.Y. State Crime Victims Bd., 502 U.S. 105, 118 (1991); Arkansas Writers' Project, 481 U.S. at 231; Minneapolis Star \& Tribune Co. v. Minnesota Comm'r of Revenue, 460 U.S. 575, 586 (1983). 


\section{APPLYING THE DOCTRINE TO SOME CASES}

\section{A. The Wartime Election}

The problem with the strict scrutiny framework is that if taken seriously it would reach results startlingly at odds with some fundamental free speech principles.

Consider the following example: The United States is fighting a slow, limited, Vietnamesque war against, say, Serbia. (For the sake of simplicity, assume that we are the key partner in the coalition, and that our departure would mean a Serbian victory.) Things seem to be going slowly in our favor, but the Serbs appear able to hold out until at least the next election. The current U.S. administration is offering the Serbs peace on relatively harsh terms.

The U.S. presidential campaign is about to start, and Congress is concerned: What if some candidates announce that they'd give the Serbs a more favorable offer? If this happens, the Serbs might refuse to come to terms until after the election, hoping a dovish candidate will win. And, of course, every month that peace is delayed could mean thousands of lost lives, both American and foreign. So Congress passes a law that prohibits all prospective presidential candidates from saying that they'd offer peace terms lighter than those the current administration is proposing. ${ }^{43}$

Such a law should be unconstitutional, even if one believes that more speech restrictions should be allowed in wartime than in peacetime. This is not a ban on revealing the sailing dates of troopships, or even on encouraging people to resist the draft. This bars a candidate from bringing before the voters alternatives that they, as the sovereign power in a democracy, are entitled to consider. They've considered such alternatives in wartime elections throughout American history, especially in 1864, 1968 and 1972. Surely their right to consider these alternatives is a key aspect of democracy, precisely because so much rides on their decision.

But, the Court tells us, content-based speech restrictions are constitutional if they pass strict scrutiny-if they "are narrowly tailored to serve a compelling state interest." ${ }^{44}$ (Of course,

${ }^{43} \mathrm{I}$ am indebted to my colleague Daniel Lowenstein for this example.

${ }^{44}$ See cases cited supra note 1 . Some have suggested that this law might be per se unconstitutional-whether or not it passes strict scrutiny-because it's viewpointbased. This might be an appealing principle, but I don't believe it is the doctrine. See 
the fact that the speech here relates to elections doesn't give it any protection greater than does strict scrutiny; the three cases that have upheld speech restrictions under the strict scrutiny framework-Buckley v. Valeo, ${ }^{45}$ Austin v. Michigan Chamber of Commerce $^{46}$ and Burson v. Freeman ${ }^{47}$-all involved election-related

R.A.V., 505 U.S, at 392-94 (applying strict scrutiny to a regulation that the Court had earlier in the opinion condemned as viewpoint-based); Capitol Square Review \& Advisory Bd. v. Pinette, 115 S. Ct. 2440, 2446-47 (1995) (plurality) (applying strict scrutiny to a restriction on religious advocacy, the sort of restriction that the Court on the same day held to be viewpoint-based in Rosenberger v. Rector \& Visitors of the Univ. of Va., 115 S. Ct. 2510, 2517 (1995)); Texas v. Johnson, 491 U.S. 397, 412 (1989) (applying strict scrutiny to a law that barred flag desecration); cf. Madsen v. Women's Health Ctr. Inc., 114 S. Ct. 2516, 2523 (1994) (mentioning, without disagreement, the challengers' claim that an injunction that is "content or viewpoint based" should be subjected to strict scrutiny).

I recognize that the Court has never specifically faced this question, and has at times hinted that the rule for viewpoint-based restrictions may be more stringent than for content-based restrictions. See Boos v. Barry, 485 U.S. 312, 319 (1988); Members of the City Council v. Taxpayers for Vincent, 466 U.S. 789, 804 (1984) (Stevens, J., who generally does not endorse the strict scrutiny framework, writing for the majority). Moreover, the Court has at times said that speech restrictions imposed by the government as proprietor of a nonpublic forum must be viewpoint-neutral. See e.g., Perry Educ. Ass'n v. Perry Local Educators' Ass'n, 460 U.S. 37, 46 (1983). If that's so, then it would seem that speech restrictions imposed by the government as sovereign would also have to be viewpoint-neutral.

But the Court has also described the ban on viewpoint-based restrictions in nompublic fora as only a "presum[ptive]" ban, Rosenberger, 115 S. Ct. at 2517 (citing Perry), and has been willing to consider a claim that a viewpoint-based restriction on speech in a nonpublic forum passes muster under strict scrutiny, see Lamb's Chapel v. Center Moriches Union Free School Dist., 508 U.S. 384, 39495 (1993). This, coupled with the cases cited at the beginning of the footnote and with the Court's general assertion that restrictions which are "narrowly tailored to serve a compelling state interest" are constitutional, suggests that the orthodox view is still that all restrictions, including viewpoint-based ones, are valid if they pass strict scrutiny.

If, however, the examples given in Parts II.A and II.B show that viewpoint-based restrictions must be per se impermissible-a rule that the Court has not yet settled on-then the examples have done their job. As I mention below in Part V, it's precisely these sorts of categorical rules, such as "viewpoint-based restrictions are per se unconstitutional," that the Court should be developing, instead of focusing so much on means-ends scrutiny. (If the Court does set forth such a rule, though, it ought to provide a coherent definition of viewpoint neutrality, something it has not yet done. Compare, e.g., Rosenberger, 115 S. Ct. at 2517-18 (holding that a distinction between religious speech and nonreligious speech was viewpoint-based) with id. at 2548-51 (Souter, J., dissenting) (arguing the contrary); Boos, 485 U.S. at 319 (holding, in my view incorrectly, that a ban on speech critical of foreign governments was viewpointneutral)).

45424 U.S. 1 (1976).

${ }^{46} 494$ U.S. 652 (1990).

47504 U.S. 191 (1992) (plurality). 
speech.) What answer, then, does the official strict scrutiny framework yield?

\section{Compelling Interest}

The government interest in winning the war more quickly-and in preserving lives-is as compelling as they come. ${ }^{48}$ The interest is not in "prohibit[ing] the expression of an idea simply because society finds the idea itself offensive or disagreeable." ${ }^{49}$ The interest is in winning the war, not simply in suppressing ideas.

Some might suggest that the interest is impermissible because it's an interest in winning the war through the suppression of speech. This argument, though, confounds the two prongs of the test. The government doesn't want suppression of speech for its own sake. Rather, the government's interest is in the enemy quickly accepting the peace terms, just as the interest the Court accepted as compelling in Buckley was in avoiding corruption. In both cases, the suppression of speech is only the means by which the interest is served. If there is any sense in separating the inquiry into the end from the inquiry into the means-and the strict scrutiny framework assumes there is sense in this-then the interest must be the goal the government is serving, without reference to the means it's using.

But even if one reads the interest here as including a "through the suppression of speech" clause, there can't be anything per se unacceptable about this interest. The premise of strict scrutiny is that sometimes the government may suppress speech and suppress ideas, so long as the means of suppression is narrowly tailored to serve a compelling end.

In Burson, for instance, the interest in preventing fraud and intimidation was jeopardized by people communicating their ideas, and was served by suppressing this communication. ${ }^{50}$ In Austin the interest in preventing corruption and the "corrosive and distorting effects [on the political process] of immense aggregations of wealth" was jeopardized by corporations communicating their ideas, and was served by suppressing this communication. ${ }^{51}$ Despite this resulting suppression, a plurality in Burson and a majority in Austin concluded

${ }^{43}$ Some might argue that winning the war more quickly is not a compelling interest for all wars; I cannot imagine, however, a court being willing to make such a judgment.

${ }^{49}$ Texas v. Johnson, 491 U.S. 397, 414 (1989).

${ }^{50}$ See Burson, 504 U.S. at 211.

${ }^{51}$ Austin, 494 U.S. at 660. 
that the law passed strict scrutiny; even the Burson dissent didn't doubt that the interest was compelling. ${ }^{52}$

\section{Narrow Tailoring-Advancement of the Interest}

The factual predictions underlying the law seem eminently plausible. If the Serbs think they might get a better peace if a certain candidate is elected, they have a powerful incentive to keep fighting.

Granted, candidates' statements might not make a difference in some situations, for instance if the Serbs can't hold out until the election regardless of who is likely to win, or if they will fight to the end in any case. But in many other circumstances, an enemy might indeed behave differently depending on the various presidential candidates' views. "Dissension within a country is a high source of comfort and assistance to its enemies; the least intimation of it they seize upon with jubilation. There cannot be the slightest question of the mischievous effects of such agitation upon the success of the national project ...."53 Surely this is especially true when one of the dissenters is a candidate for president.

Of course, the candidates will have views, whether enunciated or not. If the enemy knows that, for example, Governor Jones has dovish opinions, even if he's not expressing them in his campaignor even if the law forces him to express contrary views in the campaign-the enemy might still decide to wait to see if Jones is elected.

${ }^{52}$ See id. at 655; Burson, 504 U.S. at 218 (Stevens, J., dissenting). The Court has occasionally suggested that the interest must be "legitimate and compelling," FEC v. National Conservative Political Action Comm., 470 U.S. 480, 496-97 (1985); cf. Palmore v. Sidoti, 466 U.S. 429, 432-33 (1984) (dealing with equal protection in the race classification context); Dunn v. Blumstein, 405 U.S. 330, 345 (1972) (dealing with equal protection in the voting context), but this doesn't change the analysis in our hypothetical case: Surely the interest in having the war end more quickly is legitimate as well as compelling. (Perhaps all compelling interests are by definition legitimate.)

Certainly the Court has never suggested that the "legitimate interest" requirement calls for any extra inquiry beyond that described in the text. The most explicit statement that I have seen of the "legitimacy" requirement- "to pass constitutional muster, [a race classification] must be justified by a compelling governmental interest and must be 'necessary ... to the accomplishment' of [its] legitimate purpose"merely seems to use "legitimate purpose" to refer back to the "compelling governmental interest" phrase. Palmore, 466 U.S. at 432-33 (citations omitted).

${ }^{53}$ Masses Pub. Co. v. Patten, 244 F. 535, 539 (S.D.N.Y. 1917) (Hand, J.) (holding that such speech is protected despite its potentially adverse consequences). 
But even if Jones's general views are partly known-which will not always be so, especially if he is currently only a governor and not a federal official - there's a big difference between what he said before the campaign and what he says on the campaign trail. Jones is probably much more likely to feel bound by his announced platform than by any views he might have expressed before he began his campaign. Moreover, if he is elected, he'll have a much easier time implementing an announced policy, for which he can credibly claim he has a popular mandate, than an unannounced one. Campaign statements should thus matter a great deal to the enemy's resolve.

The law would not by itself go far in advancing the government interest; but the Court has never demanded that the law make a particularly huge dent in the problem it's trying to solve. Certainly the contribution restrictions upheld in Buckley didn't go far by themselves in preventing corruption-the Federal Election Campaign Act never purported to address all aspects of corruption. ${ }^{54}$ Likewise, the law upheld in Burson was one of the less potent tools that the state had for "protecting voters from confusion and undue influence" or protecting the election process from fraud. ${ }^{55}$ The Court, though, was untroubled by this; it demanded only that the law in some measure advance the interest, not that it advance it remarkably far. ${ }^{56}$

One can undoubtedly construct scenarios in which the campaign speech restriction wouldn't actually serve the asserted interest. It's possible that the Serbs would be emboldened by the law's passage

54 See Buckley v. Valeo, 424 U.S. 1, 7 (1976).

${ }^{55}$ Burson, 504 U.S. at 199.

${ }^{56}$ See id. Our hypothetical restriction would not be trivial to evade. A candidate may try to convey his views by indirection, but it's not easy to be subtle in sound bites addressed to an audience of over a hundred million potential voters. If a candidate finds that he can't effectively communicate a message-or expects that he won't be able to effectively defend his views once he makes them into an issue-he may just avoid making that message part of his platform. Furthermore, indirect statements suggesting a willingness to offer better terms might embolden the enemy (especially the enemy public, which might be less sophisticated than the enemy leadership) less than would direct campaign promises.

Of course, some candidates might nonetheless successfully evade the law, thus jeopardizing the government interest with relative impunity; but this is always a possibility for any law. The law in Austin v. Michigan Chamber of Commerce could probably be evaded by a corporation that was willing to start a newspaper or magazine (which were exempted from the law's operation, see 494 U.S. 652, 666-67 (1990)). Under the Buckley regime, a contributor can in some measure evade the contribution limits by making independent expenditures, which also have some potential for corruption. The Court did not, however, conclude that the possibility of evasion kept the laws from being narrowly tailored to the government interest. 
because they saw it as evidence that the United States thought itself in trouble, or would hope that the law would cause so much libertarian resistance that the U.S. war effort would be underminedpossible, but not particularly likely. If the Court gives the salutary effects of speech every possible benefit of the doubt, and views the harmful effects of speech with maximal skepticism, any speech restriction can be condemned as unnecessary or even counterproductive. I'm not sure, however, that this is an honest way of evaluating the likely effectiveness of a speech restriction; and it certainly is not the approach the Court took in Burson, Austin or Buckley. ${ }^{57}$

\section{Narrow Tailoring-Overinclusiveness}

For the same reasons, the law is not overinclusive. All the forbidden speech can jeopardize the government interest; all statements by a presidential candidate suggesting that he'd offer mild terms can indeed encourage the enemy to keep fighting.

True, we can't identify precisely the harm that flows from any one statement; it could be that, viewed in retrospect, some isolated statements did not by themselves have any appreciable effect. But that doesn't make the law overbroad. Not every campaign contribution or coordinated expenditure leads to corruption. ${ }^{58}$ Not every instance of electioneering near polling places intimidates voters; all one can say is that some such electioneering "may ... drive the voter[s] away," and that this represents a "potential deficienc[y] in the electoral process." ${ }^{\text {N9 }}$ Not every independent expenditure by a corporation on behalf of a political candidate has a corrosive effect on the political process-all they have is a "potential for distortion." 60 Strict scrutiny does not demand (and cannot demand) that every restricted statement have a provable, identifiable harmful effect. If it did, no restrictions would ever pass strict scrutiny.

${ }^{57}$ See Burson, 504 U.S. at 211; Austin, 494 U.S. at 660; Buckley, 424 U.S. at 26-27.

${ }^{58}$ See Buckley, 424 U.S. at 30.

${ }^{59}$ Burson, 504 U.S. at 207, 209 (emphasis added) (internal quotation marks omitted).

${ }^{60}$ Austin, 494 U.S. at 661 (emphasis added). 


\section{Narrow Tailoring-Least Restrictive Alternative}

Nor are there any less restrictive alternatives that will still further the interest equally well and thus avoid "unnecessarily interfering with First Amendment freedoms." ${ }^{61}$ Any alternative seems quite likely to "fall short of serving [the] compelling interests."62

Counterspeech is pointless-leaders of the current Congress might say "No, no, we'll continue to offer harsh terms to the Serbs no matter what," but how much can they do if the dove indeed gets elected? Congressional leaders might say, "No, no, don't elect this traitor," but so long as he seems viable in the polls-and viability does not mean that a current majority of voters support him, only that he has enough support that his election remains a possibilitythe Serbs will keep fighting and Americans will keep dying. Finally, the Administration might redouble its military efforts and try to force the Serbs to surrender before the election; but that might not work, and might in any event lead to even more casualties.

\section{Narrow Tailoring-Underinclusiveness}

It's also hard to see how the law is underinclusive. It bars a class of statements that is especially likely to make the enemy hold out; few other statements pose a comparable danger. Perhaps one might argue that similar statements by congressional candidates are equally dangerous-if so, then assume a law that does go that far.

So the law, it seems to me, is narrowly tailored to a compelling interest. It advances the interest, it is not overinclusive, it is not underinclusive, and there are no less restrictive alternatives. But it still seems clearly unconstitutional. ${ }^{63}$

${ }^{61}$ Sable Communications v. FCG, 492 U.S. 115, 126 (1989) (emphasis added).

62 Burson, 504 U.S. at 206; see also Buckley, 424 U.S. at 28.

${ }^{63}$ Some readers have suggested this example might be implausible because no Congress would pass this sort of law. I'm not sure about that; I can imagine decent (though misguided) wartime legislators voting for it. But, as my colleague David Sklansky has pointed out, if Congress refuses to pass such a law, a big part of the reason may be that the legislators themselves believe the law violates the Free Speech Clause - that whether or not it is narrowly tailored to a compelling state interest, the law is contrary to basic principles of democratic self-rule. 


\section{B. Praising Rioters}

Consider another example: The government bars speech that praises rioting, on the grounds that the speech makes it more likely that people will riot in the future. ${ }^{64}$ It seems clear that such a law would be unconstitutional. ${ }^{65}$ But can one reach that conclusion by applying strict scrutiny candidly?

\section{Compelling Interest}

The government interest in preventing death, injury and destruction of property is surely compelling. Like the interest in the first example, it is not an interest in "prohibit[ing] the ex-pression of an idea simply because society finds the idea itself offensive or disagreeable. ${ }^{n 6}$ The interest is in preventing violence, not simply suppressing communication (though, as in the first example and as in Buckley, Austin and Burson, the law accomplishes the interest by means of suppressing communication).

\section{Narrow Tailoring}

The theory of the law is that praise or even moral defense of rioting-for example, people and especially community leaders calling the riots "rebellion," or suggesting that rioting actually does good by shaking up the oppressive power structure, or arguing that the oppressed are morally justified in burning, looting and assault-

${ }^{64}$ Cf. Thomas D. Elias, TV and Radio Stations Should Be Stripped of Their Licenses If They Aren't More Responsible in Covering Civil Unrest, L.A. DAILY J., Jan. 26, 1993, at 6 (analogizing "irresponsible" coverage of the L.A. riots to "shouting 'fire' in a crowded theater"); Susan C. McMillan, Both Pro-Life and Pro-Choice Bear Responsibility, L.A. TIMES, Jan. 5, 1995, at B7 (arguing that " $[t]$ he inexcusable tolerance of the Los Angeles riots and constant threats of 'no justice, no peace' may have a link to the beating of Reginald Denny"); David Crump, Camouflaged Incitement, 29 GA. L. REv. 1, 76-78 (1994) (suggesting that the rap song Cop Killer, which seems to approve of killing policemen, should be considered unprotected speech); Chuck Philips, North Steamed at Ice T: He Wants Time Warner to Face Sedition Charges Over Rap Song, L.A. TrMES, July 2, 1992, at D1, D2 (quoting Lt. Col. Oliver North's prediction that the song will "incite violence against the men and women in blue").

${ }^{65}$ The prohibited speech is certainly not unprotected incitement-the law isn't limited to speech that "is directed to inciting or producing imminent lawless action and is likely to incite or produce such action." Brandenburg v. Ohio, 395 U.S. 444, 447 (1969) (emphasis added). The ban extends far beyond speech that actually takes place while the riot is going on and when the possible harm might indeed be imminent.

${ }^{66}$ Texas v. Johnson, 491 U.S. 397, 414 (1989). 
ing-will make future riots more likely and more damaging. And this seems eminently plausible.

When people know the police aren't there, the main things that stop them from rioting (other than the possibility of individual, usually violent, self-defense by their victims) ${ }^{67}$ are their own consciences and the judgments of those about whose opinions they care. Both these factors are deeply affected by what people hear from respected voices in their community.

Speech, as some have pointed out, constructs social reality. ${ }^{68} \mathrm{It}$ can turn conduct that society otherwise marks "evil" into conduct marked "good" or "tolerable" or at least "contested." If we believe that advocacy of good behavior makes it more likely that people will behave well, then it seems probable that advocacy of bad behavior, or even making excuses for bad behavior, makes it more likely that people will behave badly:

Every denunciation of existing law tends in some measure to increase the probability that there will be violation of it. Condonation of a breach enhances the probability. Expressions of approval add to the probability. Propagation of the criminal state of mind ... increases it. Advocacy of lawbreaking heightens it still further. ${ }^{69}$

Thus, the law advances the government interest, ${ }^{70}$ and it does this in a way that's not overinclusive; if the factual theory outlined above is correct, all the banned statements have the potential to

${ }^{67}$ This represents another example of the multifaceted link between the First Amendment and the Second. Cf. L.A. Scot Powe, Jr., Guns, Words, and Interpretation, 38 WM. \& MARY L. REV. (forthcoming 1997).

${ }^{63}$ See, e.g., CATHARINE A. MACKINNON, ONLY WORdS 30-31 (1993); Charles R. Lawrence III, If He Hollers Let Him Go: Regulating Racist Speech on Campus, 1990 DUKE L.J. 431, 444 (" [A]ll racist speech constructs the social reality that constrains the liberty of non-whites because of their race.").

${ }^{69}$ Whitney v. California, 274 U.S. 357, 376 (1927) (Brandeis, J., concurring). One reader suggested to me that Brandeis was conceding the point only for the sake of argument, but this does not seem to me to be so. Brandeis expressed this view as his own, without disclaimer; he acknowledged that particular forms of speech can, as an empirical matter, increase the likelihood of harm, but argued that as a normative matter they ought not be restrained. See also John H. Wigmore, Abrams v. U.S.: Freedom of Speech and Freedom of Thuggery in War-Time and Peace-Time, 14 ILL. L. REV. 539 (1920) (arguing that speech which advocates the propriety of illegal or harmful conduct does increase the likelihood of harm, and should therefore be punishable).

${ }^{70}$ Of course, as in the candidate speech example, the law is just one of the many tools the government may use to prevent rioting, and is probably not the most potent tool. But the Court has never suggested that the law has to advance the interest a great deal or in all instances, only that it has to advance the interest to some extent. See supra text accompanying notes 54-56. 
undermine the interest. ${ }^{71}$ Nor are there any less restrictive alternatives that will still avoid "unnecessarily interfering with First Amendment freedoms"72 without "fall[ing] short of serving [the] compelling interests."73 Prohibiting rioting certainly won't do the job by itself: Laws aren't always followed, especially when order has already broken down.

The government, or others, could try to counterspeak, but how effective would that be? Speech that advocates bad behavior-be it rioting, racism, bombing draft offices, bombing abortion clinics or killing police officers-is dangerous because it makes certain behavior thinkable. The very fact that some authority figures condone a form of conduct may embolden those who want to act that way. Rather than being a horrible thing that no good person would do, rioting or bombing becomes an acceptable alternative, one of many approaches to problem-solving that various people advocate. Perhaps the counterspeech might undo some of the harm, but it seems quite unlikely that it will undo all or even most of it. ${ }^{74}$

One could, of course, argue that the likely effectiveness of proriot advocacy is overstated, as Holmes and Brandeis argued in some (though not all) of their 1910 s and 1920 s free speech opinions. ${ }^{75}$

${ }^{71}$ As Part II.A.3 explains, the potential for each statement to undermine the interest is enough, even if in retrospect it turns out that some of the statements ended up not undermining the interest.

72 Sable Communications v. FCC, 492 U.S. 115, 126 (1989).

73 Burson v. Freeman, 504 U.S. 191, 206 (1992) (plurality).

${ }^{74}$ Laurence Tribe suggests that "[w] henever the harm feared could be averted by a further exchange of ideas, governmental suppression is conclusively deemed unnecessary," and thus not narrowly tailored to the interest. LAURENCE H. TRIBE, AMERICAN CONSTITUTIONAL LAW 833-34 (2d ed. 1988) (emphasis omitted). A conclusive presumption, though, is just another name for a substantive rule of law. See MCCORMICK ON EVIDENCE \$ 342, at 804 (2d ed. 1972); WIGMORE ON EVIDENCE $\S 2492$, at 308 (3d ed. 1940); $c f$. Michael H. v. Gerald D., 491 U.S. 110, 119 (1989) (plurality). If Tribe is right, then there is an additional substantive rule operating besides strict scrutiny: Even a law that is, as a factual matter, narrowly tailored to a compelling interest might be unconstitutional if the harm could be-not is certain to be, but could be-averted through further speech.

${ }^{75}$ Compare Schaefer v. United States, 251 U.S. 466, 486 (1920) (Brandeis, J., dissenting) ("It is not apparent on a reading of this article . . . how it could rationally be held to tend even remotely or indirectly to obstruct recruiting.") and Abrams v. United States, 250 U.S. 616, 629 (1919) (Holmes, J., dissenting) (describing the offending speech as "puny anonymities") and Baltzer v. United States (1918) (Holmes, J., draft dissent no. 320), reprinted in Sheldon M. Novick, The Unrevised Holmes and Freedom of Expression, 1991 SUP. CT. REV. 303, 388-90 (asserting that the offending speech "could not be imagined to do harm") with Whitney v. California, 274 U.S. 357, 376 (1927) (Brandeis, J., concurring) (agreeing that some advocacy of lawbreaking does tend to lead to lawbreaking). 
One could also argue that suppression of the speech is unlikely to do much good in any event, and that counterspeech is indeed the most practically useful response. But these are only guesses, and they strike me as guesses that are hard to support.

If simply articulating such a guess were enough to condemn a speech restriction as unnecessary and therefore unconstitutional, it's hard to imagine how any restriction would be permissible. In fact, the Court has upheld speech restrictions under strict scrutiny in the face of such guesses. The Court was not, for instance, willing to speculate that disclosure requirements alone would deter corruption as much as would a contribution ban. ${ }^{76}$ Nor was the Court willing to speculate that laws barring interference with voting would prevent such interference as well as would the ban on electioneering near polling places. ${ }^{77}$

Sometimes, the Court does make commonsense judgments that a particular less restrictive means will indeed be equally effective. ${ }^{78}$ But common sense suggests that bad speech can indeed lead to bad results, that speech restrictions might to some degree prevent such results, and that counterspeech standing alone will not always do an equally good job.

Finally, the law is not underinclusive-it bars all statements that countenance and thus indirectly encourage rioting. The law might not discourage other crimes, but advocacy of rioting is particularly troublesome because the threat of punishment is particularly ineffective when order has broken down. The construction of attitudes that tolerate rioting is thus especially dangerous. Perhaps one might say that this isn't enough of a justification for singling out praise of rioting, and that the law should also ban praise of rape and murder and robbery and such. If so-and this would make the underinclusiveness requirement toothy indeed, probably toothier than the cases warrant ${ }^{79}$ - the hypothetical can be modified accordingly.

${ }^{76}$ See Buckley v. Valeo, 424 U.S. 1, 28 (1976) (specifically rejecting the argument and finding the proposed speech restriction, a contribution ban, constitutional).

${ }_{77}$ See Burson v. Freeman, 504 U.S. 191, 206-07 (1992) (plurality).

${ }^{78}$ See, e.g., Meyer v. Grant, 486 U.S. 414, 427 (1988) (holding that alternatives which don't restrict speech "seem adequate" to serve the government's interest).

${ }^{79}$ Cf. Burson, 504 U.S. at 207 ("We do not . . . agree that the failure to regulate all speech renders the statute fatally underinclusive."); Austin v. Michigan Chamber of Commerce, 494 U.S. 652, 665-66 (1990) (holding that the law need not include all similar types of speech to avoid being underinclusive). 


\section{Typicality}

The praise-of-rioters example is far from unusual. I use it because I think it's particularly apt factually-it seems more obvious that legitimization of rioting would lead to bad results today than would legitimization of, say, Communist revolution-but the Court has had to deal with laws like the one I describe for decades. In fact, the arguments for suppression discussed above were largely what the Court accepted in Abrams v. United States ${ }^{80}$ with regard to speech that hinders the war effort, and in Gitlow v. New York ${ }^{81}$ with regard to advocacy of violent revolution.

In more recent times, many who advocate restrictions on racist and sexist speech have argued that these restrictions pass muster under the formal parameters of strict scrutiny. ${ }^{82}$ Preventing discrimination is, they say, a compelling interest (and the Court has generally, outside the free speech context, agreed).$^{83}$ The restrictions on bigoted speech serve this interest, and are neither overinclusive nor underinclusive in serving it. And the less restrictive alternatives-prohibiting discrimination or racial violence as such, and counterspeaking-might not be very effective. ${ }^{84}$

${ }^{80} 250$ U.S. 616,624 (1919).

81268 U.S. 652,669 (1925).

${ }^{82}$ See MACKINNON, supra note 68, at 107; Richard Delgado, Professor Delgado Replies, 18 HARv. C.R.-C.L. L. REv. 593, 595 (1983); Patricia B. Hodulik, Prohibiting Discriminatory Harassment by Regulating Student Speech, 16 J.C. \& U.L. 573, 582 (1990); William A. Kaplin, "Hate Speech" on the College Campus: Freedom of Speech and Equality at the Crossroads, 27 LAND \& WATER L. REV. 243, 257 (1992); Rodney A. Smolla, Rethinking First Amendment Assumptions About Racist and Sexist Speech, 47 WASH. \& LEE L. REV. 171, 183 (1990); Alice K. Ma, Comment, Campus Hate Speech Codes: Affirmative Action in the Allocation of Speech Rights, 83 CAL. L. REv. 693, 712-21 (1995); Deborah R. Schwartz, Note, A First Amendment Justification for Regulating Racist Speech on Campus, 40 CASE W. RES. L. REV. 733, 769 (1989-1990).

${ }^{83}$ See Roberts v. United States Jaycees, 468 U.S. 609, 623 (1984) (sex discrimination in the associational rights context); Bob Jones Univ. v. United States, 461 U.S. 574,604 (1983) (race discrimination in the religious freedom context).

${ }^{84}$ As I mentioned above, I agree that this speech restriction should be unconstitutional under Brandenburg $v$. Ohio-my discussion in this section has been aimed only at showing that there is a conflict between strict scrutiny and Brandenburg. Parts IV.C and $V$ explain the ways in which strict scrutiny can be modified or replaced in order to accommodate the principles of Brandenburg. 


\section{Sexually Explicit Speech and Minors}

Finally, consider a third example: The government tries to ban all distribution of sexually oriented materials that are supposedly harmful to minors but not obscene for adults. The law is clearly unconstitutional-the Court struck down such a law in 1957 in Butler v. Michigan, saying the law "burn [ed] the house to roast the pig." The Justices held that the restriction was "not reasonably restricted to the evil with which it is said to deal," pointing out that other laws already barred distribution of such materials to minors. ${ }^{86}$

But if we reconsider this under the strict scrutiny framework that supposedly governs today, why isn't the law permissible? The interest in "shielding minors from the influence of [indecent] literature that is not obscene by adult standards," the Court has since held, is compelling. ${ }^{87}$ I'm not sure that's right, but that's what the Court has said.

In Sable Communications v. FCG, the Court did strike down a ban on dial-a-porn, on the grounds that there were less restrictive alternatives, such as a requirement that the service ask for the caller's credit card number before continuing with the call. ${ }^{88}$ But these alternatives mattered because " $[t]$ here [was] no evidence ... that enterprising youngsters could and would evade the rules." 89 "For all we know from this record," the Court asserted, "[these alternatives] would be extremely effective, [and i]f this is the case, it seems to us that [the law] is not a narrowly tailored effort to serve the compelling interest of preventing minors from being exposed to indecent telephone messages." ${ }^{90}$ The pregnant negative-and this is consistent with the other least restrictive means cases-is that if the alternatives were likely to be ineffective, the law would be narrowly tailored.

Unlike phone sex services, sexually explicit books and magazines don't have credit card verification mechanisms. The only way to shield minors even halfway effectively from such publications is to ban them outright; if you let them be distributed to adults, they'll inevitably become accessible to children (even if distribution to children is outlawed). Certainly the alternative suggested by Butler

${ }^{85} 352$ U.S. 380,383 (1957).

${ }^{86} I d$.

${ }^{87}$ Sable Communications v. FCC, 492 U.S. 115, 126 (1989).

${ }^{83}$ See id.

${ }^{89} \mathrm{Id}$. at 128.

${ }^{90}$ Id. at $130-31$. 
v. Michigan would "fall short of serving [the] compelling interest[]"; il it would be a less restrictive alternative, but also a much less effective one.

Nor can the Butler law be condemned as overinclusive in the sense in which overinclusiveness is used in the cases. Each sexually explicit book sold to an adult might fall into a child's hands. Of course, many such books won't actually end up accessible to children, but then again many campaign contributions won't actually lead to corruption, and much electioneering near polling places won't actually intimidate voters. So long as each instance of the prohibited speech might implicate the interest-so long as we cannot tell whether it will or it won't-it's hard to condemn the prohibition as overinclusive.

\section{Possible Defenses of Strict Scrutiny}

\section{Strict Scrutiny as Balancing}

Some people with whom I've discussed the above examples have suggested that there might be something to strict scrutiny that I'm missing. The narrow tailoring inquiry, they say, is more than just an inquiry into advancement of the interest, overinclusiveness, underinclusiveness and less restrictive means. It also contains an element of balancing. Under it, the Court should ask whether the degree to which the law serves the interest, compelling though the interest may be, is nonetheless outweighed by the degree to which the law abridges valuable speech.

Alternatively, they say, the compelling interest inquiry is more than just an inquiry into whether the government interest is strong enough: It is also an inquiry into whether the benefit to the government interest is outweighed by the harm to the equally compelling interest in free speech itself. Under either approach, the Court might say, for instance, that the benefit to the war effort (and to the lives of our soldiers) which would be gained by the speech restriction is outweighed by the cost to deliberative democracy that the restriction imposes.

I sympathize with the normative theory behind this view, but I do not think this approach is "strict scrutiny" as traditionally understood. To begin with, this isn't what the Court says when it talks of strict scrutiny. The phrases "compelling state interest" and "narrow

${ }^{91}$ Burson v. Freeman, 504 U.S. 191, 206 (1992) (plurality). 
tailoring" do not on their face include either of the "balancing" inquiries described above. The interest inquiry seems to focus only on the importance of the government's ends: Is the interest compelling? If the answer is yes, the interest inquiry appears to stop. Likewise, the tailoring inquiry seems to focus only on the means-ends fit: Is the law the best practicable way of serving the interest?

The cases don't go into the balancing approaches identified above either. Austin v. Michigan Chamber of Commerce ${ }^{92}$ and the plurality in Burson v. Freeman, ${ }^{93}$ for instance, engage in the compelling-interest/narrow-tailoring inquiry I outlined in Part I: They look at how compelling the interest is; they ask whether the law serves the interest and whether the law is overinclusive, underinclusive, or not the least restrictive means; and they don't do any "balancing" beyond this, even though election-related speech is generally seen as being at the core of Free Speech Clause protections. $^{94}$ A lower court judge or a government official who reads these cases for guidance would, I think, read them as demanding only the conventional compelling-interest/narrow-tailoring analysis. ${ }^{95}$

Strict scrutiny can be described as a "balancing test" only in the sense that it-like most constitutional tests-tries to strike a balance between the claims of the opposite sides. Government interests that

92494 U.S. 652 (1990).

93 504 U.S. 191 (1992).

${ }^{94}$ See supra text accompanying notes $45-47$.

${ }^{95}$ I've found only one recent case that used a balancing approach for evaluating content-based restrictions on core protected speech: Butterworth v. Smith, 494 U.S. 624 (1990). Butterworth struck down a law that banned grand jury witnesses from ever disclosing the testimony they gave before a grand jury. Chief Justice Rehnquist's opinion for a unanimous court said that the Court had to "balance respondent's asserted First Amendment rights against Florida's interests in preserving the confidentiality of its grand jury proceedings." Id. at 630 . The opinion concluded that the "effect of the ban [in serving the government interests] is marginal at best and insufficient to outweigh the First Amendment interest in speech involved." Id. at 634.

Butterworth, however, is quite an unusual opinion. It uses the language of balancing instead of the language of strict scrutiny, rather than as a seeming synonym for strict scrutiny. Nowhere does the opinion acknowledge that the formal test is that a speech restriction must be narrowly tailored (or necessary) to a compelling state interest. Chief Justice Rehnquist has generally taken a fairly narrow view of Free Speech Clause protections, and has not seemed to be a great fan of genuinely strict scrutiny of content-based speech restrictions. Butterworth appears to be more an artifact of the Chief Justice's general Free Speech Clause minimalism than of any firm acceptance by the Court of balancing as a technique for resolving free speech strict scrutiny cases. In fact, Butterworth has never been cited by a Supreme Court opinion for the proposition that balancing is the proper approach, and has never been cited by a Supreme Court majority at all. 
are not compelling are outweighed by the free speech interest; if the interest, however, is compelling and the law is narrowly tailored to it, the balance comes out in the other direction. At least this is what is suggested by the language of the test and the Court's description of how it applies the test.

If one departs from this conventional model, and injects an extra balancing element-an inquiry into whether the need to serve the compelling government interest is outweighed by the need to protect free speech-then this element will become the true focus of the inquiry. This is where a court would have broad discretion to strike down a law. Silently packing the discretion into either the "compelling state interest" prong or the "narrow tailoring" prong will only confuse. Better to come out and say that narrow tailoring to a compelling interest isn't the whole story, and that there is an additional test the law must meet.

\section{Strict Scrutiny as Presumption or as Non-Exclusive Guide}

Some other readers have suggested that strict scrutiny might have been meant only as a presumption: Applying strict scrutiny yields the first cut at an answer, but the presumption might be rebutted, either by the challenger or by the state. Or perhaps the presumption is conclusive one way but rebuttable the other-being narrowly tailored to a compelling interest is necessary for a law to be valid but not sufficient. Finally, perhaps strict scrutiny is not really a rule but is rather a guide for legislators and lower courts in exercising their judgment: It reminds them that they should consider various things in their decisionmaking-whether the law advances a compelling interest, whether it's overinclusive, whether it's the least restrictive means, and whether it's underinclusive-but does not purport to set forth an exhaustive list.

As with balancing, though, this is not what the Court says. "To determine whether [a restriction is constitutional]," the Court tells us, "we must ascertain whether it burdens the exercise of political speech and, if it does, whether it is narrowly tailored to serve a compelling state interest." 96 Once that latter determination is made, the Court says the law is valid. Many cases say the test is whether the law is narrowly tailored to a compelling state interestI've seen none that say this is just the start of the inquiry.

${ }^{96}$ Austin, 494 U.S.'at 657. 
Perhaps legislators, given their independent obligation to construe the Constitution, might conclude that a law is unconstitutional even though it passes strict scrutiny. But nothing in the Court's opinions suggests that lower courts have the same option. A strict-scrutiny-as-presumption approach might be better than the current one, though a court that accepts it would then have to decide what it takes to rebut the presumption. It is not, however, the approach prescribed by the Court's decisions.

My conclusion, then, remains: Strict scrutiny, as the Court has described it, does not reach the correct result in the examples given above.

\section{The Harms Caused by StRICt ScRUtiny}

If the above criticisms are correct, the doctrine can cause three kinds of problems:

\section{A. Wrong Results}

First, decisionmakers might follow the doctrine and reach wrong results because of it. A court (either a lower court or the Supreme Court itself) applying strict scrutiny might uphold a law even though the principles underlying the free speech doctrine-those principles that lead us to condemn the laws described in Part II-suggest that the law should be struck down. ${ }^{97}$ Likewise, legislators and administrators might enact speech restrictions that seem to pass muster under strict scrutiny, but that conflict with deeper free speech principles.

\section{B. Stretching the Doctrine}

Second, courts might try to avoid the wrong results by ignoring or stretching the doctrine, striking down a law even though the law would pass strict scrutiny faithfully applied. This seems to happen fairly often.

Consider, for instance, the Court's discussion of least restrictive means in Riley v. National Federation of the Blind. ${ }^{98}$ Riley struck down a requirement that charitable solicitors reveal what fraction of the

${ }^{97}$ See, e.g., Bering v. Share, 721 P.2d 918 (Wash. 1986) (upholding a ban on antiabortion picketers using the words "murder," "kill" and their derivatives to refer to clinic doctors, staff and patients in the presence of children aged 12 or younger).

${ }^{98} 487$ U.S. 781 (1988). 
funds they raise actually ends up in the charity's hands. ${ }^{99}$ The State argued that the law was needed to better inform donors, but the Court held that there were less restrictive alternatives, such as "the State . . . itself publish [ing] the detailed financial disclosure forms it requires professional fundraisers to file." ${ }^{100}$ Such a procedure, the Court said, "would communicate the desired information to the public without burdening a speaker with unwanted speech during the course of a solicitation," and would thus be "in keeping with the First Amendment directive that government not dictate the content of speech absent compelling necessity, and then, only by means precisely tailored."101

But it's not clear how publication by the state is even close to an effective substitute for requiring the fundraisers to reveal this information when they make their pitch. Who's going to run to a state office to get these forms before contributing her money?

The Court's inquiry into whether the expenditure limitation in Buckley $v$. Valeo advanced the interest in avoiding corruption seems similarly problematic. The Court said that the ban on independent expenditures "fail[ed] to serve any substantial governmental interest in stemming the reality or appearance of corruption." ${ }^{102}$ The lack of coordination with the candidate, it argued, made the independent spending less valuable to the candidate and thus "alleviate[d] the danger that expenditures will be given as a quid pro quo for improper commitments from the candidate." 103

This justification has some merit, but it hardly disposes of the government's argument. Many officeholders would find it hard to say no to people who helped elect them, whether the help was independent or not. Independent expenditures may have less of a corrupting tendency than direct contributions, but they have this tendency nonetheless. It's hard to see how the expenditure ban "fail[ed] to serve" the interest in avoiding corruption.

It's also odd to hold, as R.A.V. v. City of St. Paul did, that a law is not narrowly tailored to an interest because there is an alternative that would restrict more speech, including speech that doesn't implicate the interest. R.A.V. held that a ban on racially hostile

${ }^{99}$ See id. at 798. The Court concluded that the test for regulations that compel speech was the same as the test for content-based speech restrictions. See id. at 796-97.

${ }^{100} \mathrm{Id}$. at 800.

${ }^{101} I d$.

102 Buckley v. Valeo, 424 U.S. 1, 47-48 (1976).

${ }^{103} \mathrm{Id}$. at 47. 
fighting words was not "narrowly tailored" to the concededly compelling interest in allowing racial minorities to "live in peace where they wish"; 104 it reached this conclusion because a general ban on all fighting words "would have precisely the same beneficial effect." 105

Nonracially motivated fighting words, however, would not implicate the government interest, an interest limited on its face to protecting racial minorities. The city ordinance was in fact neither over- nor underinclusive with respect to this interest, and the proposed alternative would have been more restrictive than the ordinance, not less.

These judicial stretches are not cost-free. When a test is sufficiently out of step with our intuitions that even the institution which articulated it often tries to wiggle out of it, the test loses what constraining and predictive qualities it might have. It becomes much less of a guide for official behavior (by the Justices, by lower court judges, or by legislators or administrators), and it becomes a much less effective predictor of judicial decisions.

Judicial stretching can also lead the losing side to conclude that its cause is being treated unfairly. Restrictions on bigoted speech are a good example. Like the restrictions on advocacy of rioting, they seem to me to be impermissible not because they aren't narrowly tailored to a compelling interest, but in spite of their being narrowly tailored. If this is so, then it's much better for courts to say up front that strict scrutiny is the wrong test, rather than to claim strict scrutiny is the right test but then avoid candidly applying it. The latter approach will only lead to all-too-plausible charges of judicial bias. ${ }^{106}$

${ }^{104}$ R.A.V. v. City of St. Paul, 505 U.S. 377, 395 (1992).

${ }^{105}$ Id. at 395-96. I am referring here not to the main body of the R.A.V. opinion, which deals with whether the challenged ordinance could be justified under a fighting words rationale, but to the brief discussion of strict scrutiny that comes at the very end.

${ }^{106}$ See, e.g., Penelope Seator, Judicial Indifference to Pornography's Harm: American Booksellers v. Hudnut, 17 GOLDEN GATE U. L. REV. 297, 313 (1987) (criticizing American Booksellers Ass'n v. Hudnut, 771 F.2d 323 (7th Cir. 1985), affd, 475 U.S. 1001 (1986), for "accord[ing] the compelling state interest in sex equality no weight"); cf. Patricia G. Barnes, A Pragmatic Compromise in the Pornography Debate, 1 TEMPLE POL. \& GIV. RTS. L. REV. 117, 123, 132 (1992) (criticizing Hudnut for supposedly asserting that "the harm that women suffer from pornography, encompassing everything from sex discrimination to battery and rape, is not as compelling as the message of violence against women that is commercially marketed by the pornography industry"); Tom Foley, Hate Crimes: An Analysis of the View from Above, 18 WM. Mrtchell L. Rev. 903, 904, 909 (1992) (concluding that the R.A.V. v. City of St. Paul 


\section{The Bad Doctrine Drives Out the Good}

Worst of all, the focus on strict scrutiny distracts the Court from the important business of searching for a better framework. Maybe Buckley was right to strike down the ban on independent expenditures, because a law that bars people from taking out an ad in the New York Times to speak their mind about a candidate is inconsistent with basic free speech principles. Maybe the Constitution requires the government to tolerate whatever risk of corruption such independent spending might cause. Maybe R.A.V. was right, because the Free Speech Clause prohibits viewpoint-discriminatory rules even if they pass strict scrutiny.

But none of these conclusions really fits within the strict scrutiny framework. Trying to shoehorn them into categories of "compelling interest" and "narrow tailoring" simply obscures the more important inquiry into what the rules ought to be.

\section{IV. "THE THEORY OF OUR CONSTITUTION"}

\section{A. The Pre-Strict Scrutiny Free Speech Cases}

As I mentioned before, if one looks at the majority opinions in Gitlow v. New York ${ }^{107}$ and other cases that upheld bans on advocacy of illegal conduct (such as Dennis v. United States ${ }^{108}$ ), one sees something not far from the strict scrutiny framework. The opinions stressed that the government interest was compelling; the speech presented "a sufficient danger of substantive evil," "danger to the public peace and to the security of the State," and the threat of "breaches of the peace and ultimate revolution." 109 The danger was "real and substantial"; while some revolutionary advocacy might fall on deaf ears, other speech "may kindle a fire that, smoldering for a time, may burst into a sweeping and destructive conflagration."110 (The world had just witnessed such conflagrations in the years

majority was "either unable or unwilling ... to see some of the most pressing constitutional issues," and criticizing it for misapplying strict scrutiny); Andrea L. Crowley, Note, R.A.V. v. City of St. Paul: How the Supreme Court Missed the Writing on the Wall, 34 B.C. L. REv. 771, 798 (1993) (criticizing the R.A.V. majority for misapplying strict scrutiny and concluding that its actions "reveal[] that it does not find racially prejudiced speech and conduct morally culpable").

107268 U.S. 652 (1925).

${ }^{108} 341$ U.S. 494 (1951).

109 Gitlow, 268 U.S. at 669; see also Dennis, 341 U.S. at 509.

110 Gitlow, 268 U.S. at 669; see also Dennis, 341 U.S. at 510-11. 
before, in the Russian Revolution as well as smaller revolts in other European countries.) And any less restrictive means would likely have been less effective-waiting until the threat was "clear and present" would mean bearing the burden of "actual disturbances of the public peace or imminent and immediate danger of [the State's] destruction." 111

The Court has generally repudiated the Gitlow approach, in Brandenburg $v$. Ohio ${ }^{112}$ and in the cases leading to it and following it. ${ }^{113}$ But Brandenburg's protection of the advocacy of bad conduct can't fit within the strict scrutiny framework. The problem is not that the ultimate interests asserted by the government aren't compelling; they are. Nor is the problem that the laws suppressing speech are somehow, as an empirical matter, not the most effective way of serving the interests. Subversive speech is protected regardless of whether the restriction is narrowly tailored to a compelling interest. ${ }^{114}$

"[T] he best test of truth," Justice Holmes said, "is the power of the thought to get itself accepted in the competition of the market." ${ }^{115}$ But he did not, and could not, assert this as empirically provable fact. Rather, he followed his statement by saying: "That at any rate is the theory of our Constitution." 116

Likewise, in Gitlow v. New York, Holmes did not suggest that counterspeech would effectively suppress revolutionary advocacy, and that it therefore was in fact a less restrictive but equally effective alternative. Rather, he asserted that "[i]f in the long run the beliefs expressed in proletarian dictatorship are destined to be accepted by the dominant forces of the community, the only meaning of free speech is that they should be given their chance and have their

${ }^{111}$ Gitlow, 268 U.S. at 699; see also Dennis, 341 U.S. at 509.

112395 U.S. 444 (1969).

11 See, e.g., NAACP v. Claiborne Hardware Co., 458 U.S. 886, 927-28 (1982); Hess v. Indiana, 414 U.S. 105, 108 (1973); Kingsley Int'l Pictures Corp. v. Regents, 360 U.S. 684, 689 (1959).

${ }^{114}$ Under Brandenburg, the government may restrict one narrow class of advocacy of illegal conduct: advocacy that "is directed to inciting or producing imminent lawless action and is likely to incite or produce such action.” 395 U.S. at 447. But, as discussed above, strict scrutiny would let courts uphold some speech restrictions that go beyond the Brandenburg standard-beyond speech likely to lead to imminent violence. See supra Part II.B.

${ }^{115}$ Abrams v. United States, 250 U.S. 616, 630 (1919) (Holmes, J., dissenting).

${ }^{116} \mathrm{Id}$. He also phrased the "best test of truth" statement as a possibility and not a certainty: "[W] hen men have realized that time has upset many fighting faiths, they may come to believe" this. Id. (emphasis added). I take it, though, that this was only a rhetorical device. 
way." 117 And in Whitney $v$. California, ${ }^{118}$ Justice Brandeis did not deny that bad speech could lead to bad results (he acknowledged it), nor did he argue that good counsels would always be adequate remedies for evil ones. He argued only that they were "the fitting ... ones," the ones the Framers judged appropriate, a judgment they enacted into the First Amendment. ${ }^{119}$

Holmes and Brandeis were not condemning the restrictions simply because the government's goals were not important enough, or arguing that the speech-restrictive means were unnecessary. Rather, they were arguing that the means were impermissible (except where a clear and present danger was present). Even if the speech was likely, through its persuasive powers, to undermine the most compelling of interests, the "meaning of free speech,"120 "the theory of our Constitution,"121 the judgment of "[t] hose who won our independence" about the "fundamental principle[s] of the American government," 122 required that the nation run the risk of the compelling interest being under-mined. ${ }^{123}$

Something similar is at work for sexually explicit speech. In Butler $v$. Michigan, ${ }^{124}$ the law banning the distribution to adults of explicit speech that could be harmful to minors was in fact the least restrictive means of serving the government's end, an end eventually declared compelling by Sable Communications v. FCC. ${ }^{125}$ But the Butler Court struck down the restriction nonetheless, because the law "arbitrarily curtail[ed] one of those liberties of the individual, now enshrined in the Due Process Clause ... that history has attested as

${ }^{117}$ Gitlow v. New York, 268 U.S. 652, 672 (1925) (Holmes, J., dissenting).

118274 U.S. 357 (1927).

119 Id. at 375 (Brandeis, J., concurring).

${ }^{120}$ Gitlow, 268 U.S. at 673 (Holmes, J., dissenting).

${ }^{121}$ Abrams v. United States, 250 U.S. 616, 630 (1919) (Holmes, J., dissenting).

122 Whitney, 274 U.S. at 375 (Brandeis, J., concurring).

${ }^{123}$ For a more recent iteration of this idea see Colorado Republican Fed. Campaign Comm. v. FEC, 116 S. Ct. 2309, 2329 (1996) (Thomas, J., concurring in part and dissenting in part) (concluding that " $[\mathrm{t}]$ he First Amendment . . . constrain [s] Congress' ability to accomplish certain goals," even when this requires some sacrifice of compelling state interests).

One could, of course, criticize these judgments: Perhaps what the Justices call "the theory of our Constitution" was simply their own policy preference, which they had no business trying to implement as law; perhaps Brandeis misread the opinions of "those who won our independence," and should have done more thorough originalist research. My point here is only that their judgments were based on some attempt to formulate (even if not to discern) the theoretical meaning of free speech, and not just on an inquiry into compelling state interests or narrow tailoring.

124352 U.S. 380 (1957).

125492 U.S. 115 (1989). 
the indispensable conditions for the maintenance and progress of a free society." 226 In the Court's view, the law constituted "burn [ing] the house to roast the pig."127

The trouble with burning the house to roast the pig is not just that there are better ways- "less restrictive alternatives"-to cook your dinner. Rather, it's that even if you had no other stove, you would be better off leaving the pig unroasted. It is this conclusion about the judgment of the Constitution and of history, and not strict scrutiny as applied in Sable, that is the true defense of sexually explicit speech.

In none of these cases did the Justices claim that they found any unified theory that would by itself resolve all Free Speech Clause cases. Justice Holmes wasn't arguing, for instance, that the "marketplace of ideas" model disposed of all free speech issues. The Butler Court didn't assert that the sole test in free speech matters was whether the speech furthered the progress of a free society.

Rather, the claims about theory and about the attestation of history were aimed at producing individual strands of doctrine-the "clear and present danger" test, or the rule that the government may not "reduce the adult population ... to reading only what is fit for children." 28 And the resulting doctrines, while narrow, were categorical; they called for no further inquiry into narrow tailoring or compelling interests.

Strict scrutiny, then, is not the test that is doing the heavy lifting in free speech cases. Through the force of precedents that emerged outside the strict scrutiny context, the Court has applied broader principles, principles that in the Court's view express the theory of free speech. The Court may talk strict scrutiny, but what ultimately protects speech is something else.

\section{B. Analogies from Strict Scrutiny Outside the Free Speech Context}

The same seems to be true in other strict scrutiny contexts. Consider Palmore v. Sidoti, which dealt with racial classifications. ${ }^{129}$

${ }^{126}$ Butler, 352 U.S. at 384 . The word "arbitrarily" might be read to suggest that nonarbitrary curtailments, ones that are narrowly tailored to a compelling interest, would be valid, but, as Part II.C argued, that cannot be true here: The law is far from arbitrary-it is indeed the least restrictive means of effectively serving the interest.

127 Id. at 383 .

${ }^{128} \mathrm{Id}$.

${ }^{129} 466$ U.S. 429 (1984). 
Two white parents divorced, and the mother got custody of the couple's child; the mother married a black man. A state court then awarded custody to the father, because living in an interracial household would have been against the child's best interest"despite the strides that have been made in bettering relations between the races in this country, it is inevitable that [the daughter] will ... suffer from the social stigmatization that is sure to come." 130 The Supreme Court reversed.

The Court could have argued that preventing social stigmatization of the child was not a "compelling" enough interest to justify race-conscious action, or that the fears of social hostility were exaggerated. But the Court didn't say this. "The State," it said, "has a duty of the highest order to protect the interests of minor children." "There is a risk that a child living with a stepparent of a different race may be subject to a variety of pressures and stresses," something the Court was willing to describe as an "injury. ${ }^{132}$

The reason the Court gave for invalidating the race-conscious custody decision is hard to reconcile with the formal framework of narrow tailoring and compelling interests. "[T]he reality of private biases and the possible injury they might inflict," the Court said, is not a "permissible consideration [] for the removal of an infant child from the custody of its natural mother. . . . Private biases may be outside the reach of the law, but the law cannot, directly or indirectly, give them effect. . . . The effects of racial prejudice, however real," could not justify this racial classification. ${ }^{133}$

The Court wasn't saying that the means didn't advance the interest, were overinclusive, were underinclusive, or weren't the least restrictive. It was saying that no means, no matter how narrowly tailored, would be permitted so long as their efficacy turned on "the reality of private biases" and gave effect to those biases. The only way I can see to explain this decision is as a judgment that the theory of our Constitution requires a certain result, even in the face of a possibly compelling interest and government action that may, as an empirical matter, be narrowly tailored to it. ${ }^{134}$

${ }^{130}$ Id. at 431 (emphasis omitted) (citation omitted).

${ }^{131}$ Id. at 433. Curiously, the Court called the interest "of the highest order" and "substantial," but never said it was compelling; perhaps the Court did not want to definitively resolve the question. But it certainly never said that the interest was not compelling.

${ }_{132} I d$.

${ }^{133} I d$. at $433-34$.

${ }^{134}$ Cf. RICHARD D. MOHR, GAYS/JUSTICE 207-08 (1988) (characterizing Palmore the 
Consider also a religious freedom example. It's widely assumed that the Free Exercise Clause and the Religious Freedom Restoration Act bar the application of Title VII to race or sex discrimination by churches in their choice of clergy. ${ }^{135}$ But why?

The Court has already held, in the free exercise and expressive association contexts, that the interests in stopping race and sex discrimination in education and public accommodations are compelling: ${ }^{136}$ lower courts agree that the same is true in employment. ${ }^{137}$ What could be more narrowly tailored to these interests than a prohibition on such discrimination? ${ }^{138}$

Of course, the overall social harm of allowing discrimination in one small sector of the economy is less than the harm of allowing it

same way).

${ }^{135}$ Some courts have concluded that the Free Exercise Clause protects clergy hiring decisions even after Employment Div. v. Smith, 494 U.S. 872 (1990), which rejected strict scrutiny of generally applicable laws under the Free Exercise Clause. See, e.g., EEOC v. Catholic Univ. of Am., 83 F.3d 455, 462 (D.C. Cir. 1996); Young v. Northern Ill. Conference of United Methodist Church, 21 F.3d 184, 185 (7th Gir. 1994); Scharon v. St. Luke's Episcopal Presbyterian Hosps., 929 F.2d 360, 363 (8th Cir. 1991); Van Osdol v. Vogt, 908 P.2d 1122, 1127 (Colo. 1996); Porth v. Roman Catholic Diocese of Kalamazoo, 532 N.W.2d 195, 200 (Mich. 1995); Geraci v. Eckankar, 526 N.W.2d 391, 401 (Minn. Ct. App. 1995) (somewhat confusingly shifting from the Free Exercise Clause to RFRA to the state religious freedom guarantee); Jocz v. Labor \& Indus. Review Comm'n, 538 N.W.2d 588, 596 n.13 (Wis. 1995); see also Smith, 494 U.S. at 882 (suggesting that free exercise claims might survive if linked with freedom of association claims). Other courts have held that clergy hiring decisions are protected by RFRA, which mirrors pre-Smith jurisprudence in prohibiting burdens on religious practice unless they pass strict scrutiny. See, e.g., Powell v. Stafford, 859 F. Supp. 1343, 1347 (D. Colo. 1994); see also Rayburn v. General Conference of Seventh-Day Adventists, 772 F.2d 1164, 1169 (4th Cir. 1985) (pre-Smith case protecting clergy hiring decisions); $c f$. NLRB v. Catholic Bishop, 440 U.S. 490 (1979) (strongly suggesting that clergy hiring decisions are protected by the Free Exercise Clause). The Establishment Clause might also protect churches in this context. See Rayburm, 772 F.2d at 1169 ("To subject church employment decisions . . . to Title VI scrutiny would also give rise to 'excessive entanglement' with religious institutions prohibited by the Establishment Clause.").

Title VII doesn't bar religious discrimination by churches, see 42 U.S.C. $§ 2000 \mathrm{e}-1$ (1988), but has no similar exemption for race or sex discrimination.

${ }^{136}$ See Roberts v. United States Jaycees, 468 U.S. 609, 625 (1984); Bob Jones Univ. v. United States, 461 U.S. 574, 595 (1983).

${ }^{137}$ See, e.g., EEOC v. Fremont Christian Sch., 781 F.2d 1362, 1368 (9th Cir. 1986); McLeod v. Providence Christian Sch., 408 N.W.2d 146, 151 (Mich. Ct. App. 1987); State by McClure v. Sports \& Health Club, Inc., 370 N.W.2d 844, 852 (Minn. 1985).

${ }^{13 s}$ Cf. Roberts, 468 U.S. at $628-29$ (concluding that in prohibiting discriminatory practices "in the distribution of publicly available goods, services, and other advantages," the state antidiscrimination law " responds precisely to the substantive problem which legitimately concerns' the State and abridges no more speech or associational freedom than is necessary to accomplish that purpose" (citation omitted)). 
everywhere, but that's true regardless of which small sector one identifies. It's true of clubs such as the Jaycees, but the Court has held that antidiscrimination law passes strict scrutiny there; ${ }^{139}$ it is true of employment by religious institutions generally (rather than just employment of clergy), but courts have upheld antidiscrimination law there too. ${ }^{140}$ Moreover, the compelling interest is not just the interest in solving a broad social problem-it is also the interest in protecting the economic and dignitary concerns of individuals. ${ }^{141}$ These concerns are implicated even by discrimination in a small sector of the economy, especially when the sector covers all the opportunities that the applicant most wants. ${ }^{142}$

To protect the church's right to discriminate in its choice of clergy, courts must abandon the notion that infringements of religious freedom are allowed so long as they pass strict scrutiny. In some situations, a court must hold-as lower courts generally do in clergy discrimination cases-that "the 'inroad on religious liberty' is too substantial to be permissible"143 even though the law is narrowly tailored to a compelling interest. What does the work here is not strict scrutiny, but an underlying theory of the autonomy of religious institutions.

Even outside the strict scrutiny context, talk of means-ends analysis often hides the real theoretical basis for the opinion. Consider Linmark Associates v. Willingboro, ${ }^{144}$ which involved a ban on the posting of "For Sale" and "Sold" signs. Today, this would be analyzed under the Central Hudson quasi-intermediate-scrutiny commercial speech framework. At the time, the Court talked more generally about the "important governmental objective"-in Linmark, the interest in preventing panic selling and "promoting stable,

139 See id.

${ }^{140}$ See, e.g., Fremont Christian School, 781 F.2d at 1368; McLeod, 408 N.W.2d at 151; State by McClure, 370 N.W.2d at 852 .

141 See Roberts, 468 U.S. at 625 (stating that discrimination "deprives persons of their individual dignity" as well as decreasing the overall social welfare).

${ }^{242}$ I have heard some suggest that there is no compelling interest in preventing discrimination in clergy selection because prospective clergy ought to accept the church's terms if they want to be part of it. But the premise of antidiscrimination law runs directly against this sort of "If you don't like it, go elsewhere" position; that is certainly the courts' attitude in most club membership, education, and employment cases.

${ }^{143}$ Rayburn v. General Conference of Seventh-Day Adventists, 772 F.2d 1164, 1169 (4th Cir. 1985) (citation omitted); see also Young v. Northern IIl. Conference of United Methodist Church, 21 F.3d 184, 187 (7th Gir. 1994).

144431 U.S. 85 (1977). 
racially integrated housing"-and whether the law was needed to serve the objective. ${ }^{145}$

But after examining the strength of the government interest and whether the law was necessary to serve the interest, the Court proceeded to state that " $[\mathrm{t}]$ he constitutional defect in this ordinance ... is far more basic": ${ }^{146}$ The government was trying to serve its ends by "deny[ing people] information that is neither false nor misleading." 147

The problem with the law, according to the Court, was not just that there was no important interest at stake, or that there were other means that, as an empirically demonstrable matter, would serve the interest equally well. The choice between, on the one hand, the "paternalistic approach" of serving government ends by restricting the flow of accurate information and, on the other, "assum [ing] that this information is not in itself harmful [and] that people will perceive their own best interests if only they are well enough informed," was not to be made on pragmatic grounds. ${ }^{148}$ Rather, the choice was one "that the First Amendment makes for us." "149 The perceived theory of the Constitution, not a consideration of the weight of the end or the practical efficacy of the means, was doing the work. ${ }^{150}$

Finally, this perspective might help explain why strict scrutiny has seemed much less strict in the pre-Smith Free Exercise Clause context than in Free Speech Clause and race discrimination cases. ${ }^{151}$ One

\footnotetext{
145 Id. at 94.

$146 \mathrm{Id}$. at 96 .

${ }^{147}$ Id. at 97 .

${ }^{143} \mathrm{Id}$.
}

${ }^{149} I d$. (quoting Virginia State Bd. of Pharmacy v. Virginia Citizens Consumer Council, Inc., 425 U.S. 748, 770 (1976)).

${ }_{150}$ Cf. 44 Liquormart, Inc. v. Rhode Island, 116 S. Ct. 1495, 1520 (1996) (Thomas, $\mathrm{J}$, concurring in part and in the judgment) (arguing that "all attempts to dissuade legal choices by citizens by keeping them ignorant are impermissible," whether or not they pass muster under the commercial speech intermediate scrutiny test).

${ }_{151}$ See, e.g., Christopher L. Eisgruber \& Lawrence G. Sager, The Vulnerability of Conscience: The Constitutional Basis for Protecting Religious Conduct, 61 U. CHI. L. REv. 1245,1247 (1994) (calling strict scrutiny "strict in theory but feeble in fact"); Ira C. Lupu, The Trouble with Accommodation, 60 GEO. WASH. L. REV. 743, 756 (1992) (calling it "strict in theory, but ever-so-gentle in fact"); Michael W. McConnell, Free Exercise Revisionism and the Smith Decision, 57 U. CHI. L. REV. 1109, 1110, 1127 (1990) (saying that " $[t]$ he 'compelling interest' standard is a misnomer" because the actual test the Court has applied is more lenient); James E. Ryan, Comment, Smith and the Religious Freedom Restoration Act: An Iconoclastic Assessment, 78 VA. L. REv. 1407, 1413-37 (1992) (examining the "rise and fall of the compelling interest test" in Free Exercise Clause cases). 
possible explanation for this result is that courts faced with religious freedom claims have not applied strict scrutiny honestly. Another is that neutral laws restricting conduct might indeed be narrowly tailored to compelling interests more often than are race classifications or content-based speech restrictions.

But a third piece of the puzzle might be that our underlying theory of religious freedom-the principles that might lead us to protect religious conduct even when it jeopardizes compelling government interests-is less rights-protective than our underlying theory of free speech or of racial equality. Perhaps, setting aside institutional autonomy of churches and a few other areas, even people who are committed to strict scrutiny in religious freedom cases really do believe that religious claims must yield to laws that are narrowly tailored to compelling interests.

If this is true, it might explain why the interest in stopping racial discrimination would override a religious university's free exercise rights to make race-based rules for its students, but why the same interest would not override the right to advocate racism. It is not necessarily that strict scrutiny is being underapplied in religious freedom cases, but rather that something beyond strict scrutiny is protecting speech in many free speech cases.

\section{G. Reconciling Strict Scrutiny with the Doctrine}

What, then, would a court do if faced with one of the laws described in Part II? For instance, say a legislature enacts the ban on praise of rioting. The law should be struck down under Brandenburg, which holds that advocacy of lawlessness is protected unless it "is directed to inciting or producing imminent lawless action and is likely to incite or produce such action," ${ }^{152}$ but, if I'm correct, under the strict scrutiny test the law would have to be upheld. Given that Brandenburg is still good law, what could a court do to avoid applying strict scrutiny?

The answer must be that strict scrutiny is in certain cases preempted, so to speak, by the "theory of our Constitution" as expressed in cases such as Brandenburg-that, as I suggest above, some speech restrictions are unconstitutional under Brandenburg even though they are narrowly tailored to a compelling interest. But how exactly does one draw the line between Brandenburg's zone of operation and the zone where the strict scrutiny test applies?

152395 U.S. 444, 447 (1969). 
Brandenburg might be read to suggest that the line is drawn based on the content of speech-that advocacy which doesn't rise to the level of incitement is "immunized from governmental control"153 but that can't be right. Like all other forms of speech, protected advocacy of violence can still be restricted by some of the laws that pass strict scrutiny. ${ }^{154}$ If I advocate violence near a polling place on election day, surely the law upheld in Burson v. Freeman prohibiting such speech would be as applicable to me as to anyone else. If a corporation puts out an ad advocating violence in the course of endorsing a candidate, surely the law upheld in Austin v. Michigan Chamber of Commerce would cover it.

The protection given by Brandenburg must turn on the nature of the law at issue, not just on the nature of the speech. If the law achieves its goals by means of cutting off the persuasive effect of speech, the law is per se unconstitutional, unless the speech passes the intent-imminence-likelihood test. ${ }^{155}$ As I suggest in Part II.B, this isn't a matter of the strength of the government interest or of narrow tailoring-a law that tries to keep people from

${ }^{153}$ Id. at 448.

${ }^{154}$ If a law tries to regulate sexually explicit speech, or insulting speech in public, it's not enough for the Court to conclude that the speech isn't obscenity or fighting words-after this, the Court must still consider whether the regulation passes strict scrutiny. See Sable Communications v. FCC, 492 U.S. 115, 126 (1989) (concluding that indecent speech isn't obscene and then applying strict scrutiny to see if the law is nonetheless constitutional); Texas v. Johnson, 491 U.S. 397, 409 (1989) (concluding that flag-burning isn' $t$ "fighting words" and then applying strict scrutiny to see if the law is nonetheless constitutional). Given that the Court views incitement as just another category of unprotected speech, like "fighting words" and obscenity, see, e.g., Bose Corp. v. Consumers Union, 466 U.S. 485, 504 (1984); Bigelow v. Virginia, 421 U.S. 809,819 (1975), the same principle should apply to speech that's close to incitement: The government could try to prove that such speech is unprotected incitement, but even if it fails, the government would have a chance to show that the restriction nonetheless passes strict scrutiny. Cf. Harry T. Edwards \& Mitchell N. Berman, Regulating Violence on Television, 89 Nw. U. L. REV. 1487, 1527-29 (1995) (asserting that a court considering regulation of television violence cannot simply conclude that such depiction of violence isn't unprotected incitement, but must also consider whether the regulation passes strict scrutiny).

${ }^{153}$ It may be permissible for the government to try to cut off the persuasive effects of some speech-for instance, of false statements of fact, as in Brown v. Hartlage, 456 U.S. 45, 61-62 (1982), or of commercial speech that proposes unlawful activity, see Central Hudson Gas \& Elec. Corp. v. Public Serv. Comm'n, 447 U.S. 557, 566 (1980), or of solicitation to criminal activity, see Kent Greenawalt, Speech and Crime, 1980 AM. B. Found. RES. J. 645-but this flows from the speech being of less than full First Amendment value. My discussion throughout the Essay assumes that the speech is core protected speech, the sort of speech to which strict scrutiny is generally said to apply. 
being persuaded by bad speech may effectively serve the compelling interest in preventing injury and death through the least restrictive means, and be neither overinclusive nor underinclusive. There are certain means that, under Brandenburg's vision of the theory of the Free Speech Clause, are unconstitutional regardless of how well they serve a compelling interest.

So the Brandenburg doctrine can be seen as one of two things. One can view it as a categorical rule: Speech restrictions that accomplish their ends by trying to stop people from persuading others are per se unconstitutional, regardless of whether they are narrowly tailored to a compelling interest (so long as the intent-imminence-likelihood threshold isn't crossed). Or one can see it as a third prong to the strict scrutiny test: Speech restrictions are constitutional only if they further a compelling interest, are narrowly tailored to that interest, and don't further the interest by stopping people from using speech to persuade.

\section{Alternatives to StRict SCRUtinY}

\section{A. Amending Strict Scrutiny: A New "Permissible Tailoring" Prong}

Strict scrutiny, as I argue in Parts II and III, is flawed: If taken seriously, it is hard to reconcile with our intuitions and with some important precedents, such as Brandenburg $v$. Ohio and Butler $v$. Michigan. As Part IV suggests, these precedents, among others, look to something beyond compelling interests and narrow tailoring; they articulate per se rules that, in the Justices' views, embody the theory of free speech.

The existence of these per se rules suggests two things: First, whatever doctrine the Court uses must somehow include these rules; and, second, the doctrine must take into account the possibility that other, similar rules might be created in the future. After all, if Brandenburg identifies one type of law that is unconstitutional even if narrowly tailored to a compelling interest, perhaps there might also be other types. Rather than focusing the courts solely on compelling interests and narrow tailoring, the doctrine should also focus on searching for these new categorical rules.

One way of repairing strict scrutiny doctrine, ${ }^{156}$ then, is to add

156 Cf. Robert Post, Recuperating First Amendment Doctrine, 47 STAN. L. REV. 1249, 1250 (1995) (criticizing the "internal incoherence" of various aspects of free speech 
a third prong-the "permissible tailoring" inquiry-that captures this possibility. Under this modified doctrine, a law would be constitutional if it is (1) narrowly tailored to, (2) a compelling state interest, and (3) serves the interest in a way consistent with the theory of our Constitution.

Thus, the ban on praise of rioters might be "impermissibly tailored" because under Brandenburg $v$. Ohio a law may not try to cut off the persuasive effect of political advocacy, an effect that may be the very reason why free speech is protected. The ban on distribution to adults of material that's harmful to minors would be impermissibly tailored because, as Butler v. Michigan holds, it's per se improper to entirely deprive adults of this sort of speech. ${ }^{157}$

If a ban on dovish speech by wartime candidates were enacted, a court could conclude that it's impermissible for a law to serve even the most compelling interest in a way that denies the sovereign people the ability to choose national policy. This would be a new per se principle that the Court could enunciate, and that would become part of the "permissible tailoring" inquiry. ${ }^{158}$ Similarly, outside the free speech area, a ban on discrimination by churches in clergy selection might be impermissibly tailored because it interferes with a core theoretical principle of church autonomy. The race-conscious custody decision might likewise be impermissible because it operates in a way that gives effect to private prejudices.

\section{B. Abandoning Strict Scrutiny}

It seems to me, though, that the permissible tailoring inquiry would often end up wagging the strict scrutiny dog. If part of the answer to the question "Is this law constitutionally permissible?" is "Does the theory of our Constitution permit it?" or "Is the law permissibly tailored to the interest?," it doesn't seem useful to view the framework-here the new three-prong strict scrutiny framework-as much of an answer at all. It would at most be a way of reframing the question.

It may therefore be better to shift away from the strict scrutiny approach altogether, as Justice Kennedy, concurring in Simon $\mathcal{E}^{\circ}$ Schuster v. Members of the New York State Crime Victims Board, suggested

doctrine).

${ }^{157}$ See 352 U.S. 380, 383-84 (1957).

${ }^{153}$ Compare Richard H. Pildes, Avoiding Balancing: The Role of Exclusionary Reasons in Constitutional Law, 45 HASTINGS L.J. 711 (1994), for a related though different approach. 
several years ago. ${ }^{159}$ Instead, the Court should see its task as being the development of a system of categorical rules and categorical exceptions that reflect its view of the meaning of the Free Speech Clause. Such a system would not be that different from what the Court has done (admittedly, with varying success) for many other constitutional provisions, such as the Ex Post Facto Clause, the Double Jeopardy Clause, the Criminal Jury Trial Clause and the Assistance of Counsel Clause. ${ }^{160}$ And it would not be that different from what the Court has done in other areas of free speech jurisprudence, for instance in libel cases, incitement cases and obscenity cases. ${ }^{161}$

In fact, many of the most important free speech principles were themselves developed outside the strict scrutiny framework. Contentbased restrictions are viewed with more skepticism than contentneutral restrictions because (rightly or wrongly) the Court believes that "above all else, the First Amendment means that government [presumptively] has no power to restrict expression because of its message, its ideas, its subject matter, or its content."162 The intermediate level of protection given to commercial speech is premised on the Court's vision (again, rightly or wrongly) of the "choice ... that the First Amendment makes for us," 163 and of the "commonsense differences" between commercial speech and noncommercial speech. ${ }^{164}$

Likewise, the government has a freer hand when acting as employer than when acting as sovereign because of the Court's normative judgments about when it's reasonable to expect employees to give up some part of their rights in exchange for a government

${ }^{139}$ See 502 U.S. 105, 124-28 (1991) (Kennedy, J., concurring in the judgment).

${ }^{160}$ See, e.g., Collins v. Youngblood, 497 U.S. 37 (1990) (describing the Ex Post Facto Clause test); Witte v. United States, 115 S. Ct. 2199 (1995) (Double Jeopardy Clause); Cheff v. Schnackenberg, 384 U.S. 373 (1966) (Criminal Jury Trial Clause); Wheat v. United States, 486 U.S. 153 (1988) (Assistance of Counsel Clause).

${ }^{161}$ As suggested in note 154, supra, in these cases it is possible for the Court to go into a strict scrutiny analysis-for instance, even if a statement is opinion, or is true, or was made about a public figure without actual malice, the plaintiff might still argue that a particular libel law bans the statement and passes strict scrutiny. But as a practical matter, courts do not generally do this. In practice, libel cases, incitement cases and obscenity cases operate entirely within their own framework, and do fine without any sort of strict scrutiny inquiry.

${ }^{162}$ Police Dep't of Chicago v. Mosley, 408 U.S. 92, 95 (1972) (bracketed word added to cure what in retrospect is obvious hyperbole).

163 Virginia State Bd. of Pharmacy v. Virginia Citizens Consumer Council, Inc., 425

U.S. 748,770 (1976).

${ }^{164}$ Id. at 771 n.24. 
salary. ${ }^{165}$ Similar theoretical judgments underlie the Court's conclusions that "fighting words," obscenity, child pornography and threats are unprotected; that speech restrictions in nonpublic fora must be viewpoint-neutral; and that libel recoveries involving public figures and matters of public concern are allowed only if actual malice is proven. ${ }^{166}$ To be sure, in formulating many of these principles the Court did consider the magnitude of the government interest in restricting the speech and the degree to which the restrictions served the interest; but it didn't limit itself to these inquiries.

By abandoning strict scrutiny of content-based restrictions-or perhaps even intermediate scrutiny of commercial speech restrictions-the Court can shift its focus to creating, as best it can, rules that capture its theory about the proper role of such restrictions. It could, for instance, say that content-based regulations of high-value speech imposed by the government acting as sovereign are simply per se unconstitutional (subject to the recognized exceptions). Contentbased restrictions on nonmisleading commercial speech concerning lawful activities might also be declared per se unconstitutional (subject to a perhaps larger set of exceptions).

This sort of doctrinal change would be substantial but hardly unthinkable. As I mentioned above, Justice Kennedy has already called for the abandonment of strict scrutiny of content-based speech restrictions. Justice Thomas has argued that Buckley $v$. Valeo should be partly overruled because " $[t]$ he First Amendment . . . constrain $[s]$ Congress's ability to accomplish certain goals," even when those goals (such as elimination of corruption) are compelling and when any alternatives would be less effective. ${ }^{167}$ Justice O'Connor, while willing to apply strict scrutiny in the free speech context, has shown some unease with it in the associational freedom context. ${ }^{168}$ And

165 See Waters v. Churchill, 114 S. Ct. 1878, 1887-88 (1994) (plurality).

${ }^{166}$ See, e.g, Chaplinsky v. New Hampshire, 315 U.S. 568 (1942) (fighting words); Miller v. California, 413 U.S. 15 (1973) (obscenity); New York v. Ferber, 458 U.S. 747 (1982) (child pornography); Watts v. United States, 394 U.S. 705 (1969) (threats); Perry Educ. Ass'n v. Perry Local Educators' Ass'n, 460 U.S. 37 (1983) (nonpublic fora); New York Times Co. v. Sullivan, 376 U.S. 254 (1964) (libel).

167 Colorado Republican Fed. Campaign Comm. v. FEC, 116 S. Ct. 2309, 2329 (1996) (Thomas, J., concurring in part and dissenting in part). Justice Thomas was arguing within what he described as the strict scrutiny framework; but as I describe in note 36, supra, his definition of "narrow tailoring" is quite different from the one used in the strict scrutiny cases, and perhaps ultimately more consistent with a per se invalidity approach than with traditional strict scrutiny.

163 See Roberts v. United States Jaycees, 468 U.S. 609, 632-34 (1984) (O'Connor, 
Justice Stevens, while no fan of categorical rules such as the one I propose, has long been no fan of strict scrutiny, either. ${ }^{169}$

And because so few cases-only Buckley, Austin and the Burson plurality-have actually used strict scrutiny to uphold content-based speech restrictions, shifting to a per se rule of invalidity (with room for categorical exceptions) would not substantially upset the existing regime. If the Court believes that these three cases were rightly decided, it would just have to identify why it believes this, and formulate categorical exceptions that embody its theory.

The Court might, for instance, conclude that corporate speakers are different from ordinary speakers, at least where candidate elections are involved. ${ }^{170}$ Likewise, it might conclude that the per se bar should not apply where the speech has a reasonable likelihood of intimidating voters, or where "the justification for the speech restriction is to protect another constitutional right."171 I'm not persuaded that it would be right to carve out these exceptions, but then again I'm unpersuaded by the arguments the Court gave for reaching these results under strict scrutiny.

In each case, the Court would ask the familiar questions: Does some interpretive theory-whether tied to the constitutional text, to broader constitutional or moral values, to the caselaw, or to something else-support this distinction? Is the proposed rule likely to lead to good results in most cases? Is the rule likely to be properly administered by courts and other government officials? ${ }^{172}$

$\mathrm{J}$, concurring in the judgment) (seemingly rejecting strict scrutiny in favor of a per se approach, though not criticizing strict scrutiny as explicitly as Justice Kennedy did in Simon E Schuster).

${ }^{169}$ See, e.g., Eu v. San Francisco County Democratic Cent. Comm., 489 U.S. 214, 233-34 (1989) (Stevens, J., concurring).

${ }^{170}$ See Austin v. Michigan Chamber of Commerce, 494 U.S. 652, 660 (1990). I do not necessarily mean to endorse this outcome; I only suggest that it makes more sense as a rule carving out an exception from another rule, rather than as an application of some strict scrutiny principle.

${ }^{171}$ Burson v. Freeman, 504 U.S. 191, 213 (1992) (Kennedy, J., concurring). Justice Kennedy takes the view that content-based speech restrictions should be per se invalid; he justified his vote in Burson to uphold the restriction on electioneering outside a polling place by arguing that the law fell into this categorical exception to the categorical rule. See id. at 213-14. I believe this particular exception has a great deal of potential for harm, but I agree with Justice Kennedy's general approach of looking for categorical rules and categorical exceptions. See Eugene Volokh, Freedom of Speech and the Constitutional Tension Method, 3 U. CHI. ROUNDTABLE 223 (1996).

172 See generally Alex Kozinski \& Eugene Volokh, A Penumbra Too Far, 106 HARV. L. REV. 1639 (1993). 
Sometimes the Court's answers to these questions might lead it to demand that a restriction serve a compelling government interest, or that the law not be overinclusive or underinclusive, or that it be the least restrictive means. Sometimes, it might demand less: Consider the Court's willingness to uphold copyright law and, to some extent, right of publicity law ${ }^{173}$-both of these are contentbased restrictions on high-value speech imposed by the government acting as sovereign, but it's not clear that they are narrowly tailored to a compelling state interest, and the Court certainly didn't analyze them this way. ${ }^{174}$ Sometimes though, the categorical framework might lead the Court to strike down even those restrictions that would otherwise pass strict scrutiny.

I make no claims here about what the particular rules and exceptions should be. I'm arguing that the Court should try to decide what is demanded by the "theory of the Constitution," but I'm not arguing in favor of any particular theory. The Justices already have their own views about the theory of the Free Speech Clause; all I suggest is that the law will develop better if they implement these views through the categorical approach rather than through a strict scrutiny framework.

Such a proposal, of course, leaves the inquiry somewhat indeterminate. I hope the categorical rules the Court sets forth will be fairly

173 See Harper \& Row, Publishers, Inc. v. Nation Enters., 471 U.S. 539, 560-69 (1985); Zacchini v. Scripps-Howard Broadcasting Co., 433 U.S. 562, 575-79 (1977).

Some may disagree with me on this, and conclude that the Court should always demand that proposed new exceptions be narrowly tailored to a compelling state interest; such a requirement could itself be part of the "theory of our Constitution." But even if this is so, the disagreement would only go to what the particular set of rules and exceptions should be. We could still agree that the categorical approach is superior to unvarnished traditional strict scrutiny.

${ }^{174}$ This may well be right-it may well be that no single test, even one as openended as strict scrutiny, can properly deal with all sorts of possible content-based restrictions. Justice O'Connor's criticisms of the Lemon Establishment Clause test in Board of Education of Kiryas Joel Village School District v. Grumet, seem apt in this context:

[S]etting forth a unitary test for a broad set of cases may sometimes do more harm than good. Any test that must deal with widely disparate situations risks being so vague as to be useless. ...

Moreover, shoehorning new problems into a test that does not reflect the special concerns raised by those problems tends to deform the language of the test. Relatively simple phrases ... acquire more and more complicated definitions which stray ever further from their literal meaning. . . .

Finally, another danger to keep in mind is that the bad test may drive out the good. Rather than taking the opportunity to derive narrower, more precise tests from the case law, courts tend to continually try to patch up the broad test, making it more and more amorphous and distorted.

114 S. Ct. 2481, 2499 (1994) (O'Connor, J., concurring). 
precise, but in every case there will be a possible argument for a new rule or a new exception, which will leave room for a good deal of subjective and unpredictable judgment. The Court, though, already has the power to create new categorical rules and to carve out new exceptions, whether or not the strict scrutiny framework is retained; the decision in New York v. Ferber ${ }^{175}$ that child pornography lacks First Amendment value is one example. And if I am correct, strict scrutiny as the Court applies it-and as strict scrutiny must be applied in order to avoid results that many would condemn as clearly incorrect-must contain an equally indeterminate and subjective "permissible tailoring" component.

It is better to make the nature of the inquiry explicit, and to make the Justices' constitutional choices more visible, than to leave them hidden under a false veneer of a more determinate- and objective-sounding test. I am not certain about what "the theory of the Constitution" should be, or whether one should figure it out by consulting original meaning, moral principle, pragmatic judgment, or what have you. My suggestion is only that strict scrutiny is not a helpful approach.

\section{CONCLUSION}

Contrary to the Court's announced test, some content-based speech restrictions are unconstitutional even though they are narrowly tailored to a compelling state interest. The same goes for some race classifications and some restrictions on religious freedom. The Court says that strict scrutiny is the test, but what it doescorrectly, in my view-is something quite different.

If I'm right, the Court has several options:

1. Take strict scrutiny seriously and reverse the decisions that have struck down those restrictions.

2. Continue saying that it's applying the traditional strict scrutiny framework, but nevertheless continue striking down these restrictions.

3. Add a third prong to the strict scrutiny framework that makes clear that the challenged law must not only be narrowly tailored to the compelling state interest, but must also be permissibly tailoredmust comport with the theoretical foundations of the right involved.

4. Reject strict scrutiny, and operate through categorical rules and categorical exceptions. 
I believe the fourth option is the best one, but at the very least either the third or fourth approach is necessary. It's hardly healthy for free speech law-or individual rights law more broadly-to have the announced rules be as inconsistent as they are with the decided cases. 
